\title{
Estrogen response element binding induces alterations in estrogen receptor $-\alpha$ conformation as revealed by susceptibility to partial proteolysis
}

\section{T L Ramsey and C M Klinge}

Department of Biochemistry and Molecular Biology, University of Louisville School of Medicine, Louisville, Kentucky 40292, USA

(Requests for offprints should be addressed to C M Klinge; Email: carolyn.klinge@louisville.edu)

\begin{abstract}
Genes whose expression is highly induced by estradiol $\left(\mathrm{E}_{2}\right)$ contain multiple estrogen response elements (EREs) in their promoters. Previously we reported that estrogen receptor- $\alpha(\mathrm{ER} \alpha)$ binds cooperatively to and $\mathrm{E}_{2}$ synergistically activates reporter gene expression from three or four tandem copies of a consensus ERE (EREc38). Here we evaluated how ER $\alpha$ binding to one, two, three or four tandem copies of EREc38 affects ER $\alpha$ conformation as detected by altered ER $\alpha$ trypsin digestion patterns in Western blots. $\mathrm{E}_{2}$ - or 4hydroxytamoxifen (4-OHT)-occupied ER $\alpha$ bound to the pS2 ERE or to a single copy of EREc38 showed enhanced susceptibility to trypsin digestion
\end{abstract}

compared to $\mathrm{E}_{2}$ - or 4-OHT-ER $\alpha$ incubated with DNA lacking an ERE. ER $\alpha$ binding to multiple tandem copies of EREc38 further increased sensitivity to trypsin digestion. These results correlate with synergistic transcription and cooperativity of ER $\alpha$ binding to multiple tandem copies of EREc38. These observations suggest that EREc38 binding alters the overall conformation of $\mathrm{ER} \alpha$ and that multiple tandem copies of EREc38 enhance these conformational changes. We hypothesize that EREinduced alterations in $\mathrm{ER} \alpha$ conformation modulate interaction with coregulatory proteins, resulting in synergistic transcriptional activation.

Fournal of Molecular Endocrinology (2001) 27, 275-292

\section{INTRODUCTION}

Estrogen receptor (ER) is a member of the steroid/ thyroid superfamily of proteins that act as hormoneinducible transcription factors (Mangelsdorf et al. 1995). Two ER gene products, i.e. $\mathrm{ER} \alpha$ and $\mathrm{ER} \beta$, mediate the actions of estrogens in target tissues, thus regulating estrogenic effects on reproduction, bone homeostasis, and mammary gland structure and function (Katzenellenbogen \& Korach 1997). Ligands, e.g. estradiol $\left(\mathrm{E}_{2}\right)$, bind in the ligandbinding domain (LBD) of $\mathrm{ER} \alpha$ and induce conformational changes leading to dimerization and high-affinity $\mathrm{ER} \alpha$ binding to estrogen response elements (EREs). Once bound to an ERE, interaction between specific motifs within the DNAbound ER $\alpha$ and coactivator proteins, e.g. SRC-1 (Onate et al. 1995), TIF1 (Le Douarin et al. 1995), TIF2 (Voegel et al. 1996), and the TATA binding complex, e.g. TFIIB (Ing et al. 1992) and TATA-box binding protein (Sadovsky et al. 1995), results in increased gene transcription (reviewed in McKenna et al. 1999).
Crystal structure studies of the ER $\alpha$ LBD occupied by an antiestrogen, i.e. 4-hydroxytamoxifen (4-OHT) (Shiau et al. 1998), the select ER modulator raloxifene (RAL) (Brzozowski et al. 1997), $\mathrm{E}_{2}$ (Brzozowski et al. 1997) or diethylstilbestrol (DES) (Shiau et al. 1998) show distinct changes in the positioning of helix 12, which is involved in $\mathrm{AF}-2$ function and interaction with the LXXLL-motif of coactivators. Whereas the position of helix 12 in $\mathrm{E}_{2}$ - or DES-liganded ER $\alpha$ facilitates formation of a hydrophobic groove allowing interaction with specific coactivators, displacement of helix 12 in 4-OHT- or RALliganded $\mathrm{ER} \alpha$ allows no interaction with these proteins.

We reported that $\mathrm{E}_{2}$-ER $\alpha$ binds cooperatively to stereoaligned EREs that are surrounded by naturally occurring AT-rich flanking sequences (Klinge et al. 1992a,b, 1996a,b, Anolik et al. 1993, 1995, 1996). In contrast, when ER $\alpha$ is occupied by 4-OHT, ER $\alpha$ binds EREs non-cooperatively, regardless of spacing of the EREs on the DNA helix or the presence of AT-rich ERE-flanking 
sequence (Klinge et al. 1992a, Anolik et al. 1993, 1995, 1996). Further, upon ERE binding, an allosteric change is induced in the 4-OHT-ER $\alpha$ protein and one molecule of 4-OHT dissociates from the 4-OHT-ER $\alpha$ dimer (Klinge et al. 1996a).

Response elements recognized by nuclear transcription factors, including members of the steroid/ nuclear receptor superfamily, were proposed to contain information that is interpreted by bound regulator factors (Lefstin et al. 1998). In this model, DNA is envisioned to act as an allosteric ligand whose binding alters the transcription factor's affinity for other ligands, such as coactivators or corepressors. This model predicts that the DNAbinding domain (DBD) of the $\mathrm{ER} \alpha$ harbors activities beyond DNA recognition. Indeed, the $\mathrm{ER} \alpha$ DBD constitutes surfaces for both intramolecular and intermolecular protein-protein contacts. Thus, alterations in the ER $\alpha$ conformation induced by ER $\alpha$-ERE binding are predicted to alter ER $\alpha$ interaction with other proteins, e.g. coactivators or corepressors (Klinge 2000).

$\mathrm{ER} \alpha$ conformation also depends on bound ligand. Digestion of ER $\alpha$-expressing MCF-7 cells with chymotrypsin or trypsin revealed different sized fragments of $E R \alpha$ when liganded by $E_{2}$ and tamoxifen (Hutchens et al. 1987). More recently, different trypsin digestion patterns of both ER $\alpha$ and $\operatorname{ER} \beta$ were detected when the receptors were occupied by agonist vs antagonist ligands (Kraichely et al. 2000). However, not all investigators detected ligand-specific alterations in ER $\alpha$ conformation by altered sensitivity to trypsin digestion (Fritsch et al. 1993). While specific amino acid mutations that activate $\mathrm{ER} \alpha$ were shown to result in proteolytic digestion patterns similar to those of the wild-type ERa (Lazennec et al. 1997), two reports indicate conflicting results on the effect of DNA binding on ER $\alpha$ conformation as measured by alterations in trypsin digestion (Fritsch et al. 1992b, Wood et al. 1998). One report showed that rat uterine $\mathrm{ER} \alpha$ conformation was unaffected by DNA binding (Fritsch et al. 1992b). The other report showed that yeast-expressed, recombinant human (rh) ER $\alpha$ was more sensitive to trypsin or chymotrypsin digestion when bound to the vitellogenin A2 ERE, containing a perfect palindromic ERE, than when ER $\alpha$ was incubated with the ERE from the human pS2 gene, containing a single nucleotide change in the $3^{\prime}$ half-site (Wood et al. 1998). Recently we reported that a correlation exists between $\mathrm{ER} \alpha$ binding affinity, transcriptional activation in transiently transfected cells, and sensitivity of ER $\alpha$ to $\alpha$-chymotrypsin digestion for two synthetic palindromic EREs, a direct repeat 5 sequence, and the EREs from the estrogen responsive $\mathrm{c}$-fos, progesterone receptor, and pS2 genes (Klinge et al. 2001). No one has used protease sensitivity to examine if the cooperative $\mathrm{ER} \alpha$ binding and synergistic activation of reporter gene expression from multiple EREs is reflected in altered ER $\alpha$ conformation when bound to these elements.

In the present study, we utilized trypsin digestion to compare $\mathrm{ER} \alpha$ conformation when the receptor was occupied by $\mathrm{E}_{2}$ or $4-\mathrm{OHT}$ and when $\mathrm{ER} \alpha$ was free in solution or bound to one or more tandem copies of a consensus ERE called EREc38. We report that ERE binding enhances the sensitivity of $\mathrm{ER} \alpha$ to proteolysis by trypsin. In contrast, incubation of ER $\alpha$ with DNA sequences to which $\mathrm{ER} \alpha$ does not bind does not alter $\mathrm{ER} \alpha$ sensitivity to proteolysis. We report that there is a correlation between the sensitivity of $\mathrm{ER} \alpha$ to trypsin digestion and cooperativity of ER $\alpha$-EREc3 38 binding and synergistic transcriptional activation. These results are consistent with a role for the sequence of the $\mathrm{ERE}$ as an allosteric regulator of $\mathrm{ER} \alpha$ activity.

\section{MATERIALS AND METHODS}

\section{Preparation of ERE-containing oligomers}

The sequence of the synthetic EREc38 used in these experiments is: $5^{\prime}$-CCAGGTCAGAGTGACCTG AGCTAAAATAACACATTCAG-3' (Peale et al. 1988). The sequence of the pS2 ERE is $5^{\prime}$-CTTC CCCCTGCAAGGTCAGCGTGGCCACCCCGT GAGCC-ACT-3' that was cloned into the pGL3Promoter plasmid (Promega, Madison, WI, USA) as described (Klinge et al. 1999). Single EREc38 or multiple, head-to-tail, tandem copies of doublestranded EREc38 oligomers, referred to as $n$ EREc38 where $n=$ number of tandem copies, were cloned into the pGEM-7Zf(+) or pGL3-Promoter plasmids as described (Klinge et al. 1992b, 1997b). EREc38 oligomers were prepared by restriction digestion of the pGEM-7Zf(+) plasmid with EcoRI and BamHI and electroelution (Klinge et al. 1996a). pS2 and NOTERE (containing the plasmid DNA flanking the insertion site of the EREs in pGL3-Promoter) were restricted from the pGL3Promoter plasmid by XhoI/HindIII digestion and purified by PAGE and electroelution (Klinge 1999). The concentration of the EREc38, pS2 and NOTERE oligomers was measured using the PicoGreen fluorescence assay with $\lambda$ DNA as the standard (Molecular Probes, Eugene, OR, USA).

\section{Preparation of ER}

Baculovirus-expressed $\mathrm{rhER} \alpha$ was prepared as nuclear extracts from Sf-21 cells as previously 
described (Klinge et al. 1998, 1999). ER $\alpha$ concentration was determined by $17 \beta-\left[2,3,6,7-{ }^{3} \mathrm{H}(\mathrm{N})\right]-$ estradiol $\left(\left[{ }^{3} \mathrm{H}\right] \mathrm{E}_{2}, 84 \cdot 1 \mathrm{Ci} / \mathrm{mmol}\right.$; NEN, Boston, MA, USA) binding and adsorption to hydroxylapatite (Pavlik et al. 1976). All receptor concentrations refer to dimeric $\mathrm{ER} \alpha$ (i.e. with two molecules of bound ligand).

\section{Trypsin digestion}

Liganded ER $\alpha$ (250 fmol per reaction) was preincubated with ERE $(1 \cdot 25-2 \cdot 5$ pmol per reaction), non-specific DNA (a fragment from the region of the pGEM-7Zf $(+)$ plasmid into which EREc38 was cloned), or an equal volume of TE buffer for $30 \mathrm{~min}$ at room temperature $\left(\mathrm{RT}, 22^{\circ} \mathrm{C}\right)$. Trypsin was added to give the concentration $(0 \cdot 1-1 \cdot 5 \mu \mathrm{g} / \mathrm{ml})$ indicated in the figure legends and the reaction ( $20 \mu$ l total reaction volume) was allowed to proceed for $10 \mathrm{~min}$ at RT. The reaction was terminated by addition of $6 \mu \mathrm{l}$ Laemmeli loading buffer (Klinge et al. 1997b). Samples were applied to a $10 \%$ polyacrylamide mini-SDS PAGE gel.

\section{SDS-PAGE, Western blotting and densitometric quantitation}

Proteins were analyzed on 10\% SDSpolyacrylamide mini-gels as described (Klinge et al. 1997a). For Western blotting, proteins were electroblotted onto PVDF (NEN). The transfer was monitored by transfer of the prestained protein markers (SeeBlue Standard from Invitrogen, Carlsbad, CA, USA). Following the transfer, the blots were processed as described (Klinge et al. 1997b). Multiple exposures of each blot (from $10 \mathrm{~s}$ to $4 \mathrm{~min}$ ) were taken to ensure that the film's range was not exceeded. The resulting films of the immunoblots were scanned into Adobe Photoshop v. 4.0 using a Microtek ScanMaker III scanner (Redondo, Beach, CA, USA). Un-Scan-It v. $5 \cdot 1$ for Windows (Silk Scientific, Orem, UT, USA) was used to digitalize and quantitate the amount of ER $\alpha$ in the immunoblot bands and to determine the molecular mass (MM) of each ER $\alpha$ band, based on migration of the prestained protein standards. The densitometric value from each band was entered into Microsoft Excel 97 and relative values determined. Regression analysis across multiple experiments determined $\mathrm{EC}_{50}$ values for digestion of the intact receptor. Computer analysis of the potential trypsin sites and anticipated peptide mass of the resulting tryptic fragments of the human ER $\alpha$ sequence was performed using Expert Protein Analysis System proteomics server (ExPASy) of the

www.endocrinology.org
Swiss Institute of BioInformatics; web site http:// expasy.cbr. nrc.ca/cgi-bin/peptide-mass.pl.

\section{Transient transfection experiments}

Chinese hamster ovary cells (CHO-K1) were purchased from ATCC (Manasas, VA, USA) and maintained in Iscove's Modified Dulbecco's Medium (IMDM) (Gibco BRL, Grand Island, NY, USA) supplemented with $10 \%$ fetal calf serum. All other cell culture reagents were purchased from Gibco BRL. Transient transfection was performed using Transfast (Promega) according to directions supplied by the manufacturer and as described previously (Klinge et al. 1999, 2000, 2001). Cells were treated with $10 \mathrm{nM} \mathrm{E} \mathrm{E}_{2}$ (Sigma Chemical Co., St Louis, MO, USA), $100 \mathrm{nM}$ 4-OHT (Research Biochemicals International, Natick, MA, USA), or $10 \mathrm{nM} \mathrm{E} \mathrm{E}_{2}+100 \mathrm{nM}$ 4-OHT, diluted in IMDM without phenol red. Cells were harvested $30 \mathrm{~h}$ later and luciferase and $\beta$-galactosidase $(\beta$-gal) activities assayed (Klinge et al. 1997b). All data for transient transfections were normalized by $\beta$-gal to account for transfection efficiency. Statistical analyses were performed using Student's $t$-test in Microsoft Excel 97.

\section{Other statistical treatments}

The concentration of trypsin required to decrease the amount of intact $\mathrm{ER} \alpha$ by $50 \%\left(\mathrm{EC}_{50}\right)$ was calculated from densitometric data using logistic regression (GraphPad Prism, v.3, GraphPad Software, San Diego, CA, USA). Apparent equilibrium dissociation constants $\left(K_{\mathrm{d}}\right)$ were calculated from electrophoretic mobility shift assay (EMSA) data using a one-site competition model (GraphPad Prism, v.3) (Tyulmenkov et al. 2000). These values and the mean luciferase activities from transfection experiments were dichotomized using the criteria described in the text and organized in $2 \times 2$ contingency tables to employ chi-square independence tests in Microsoft Excel 97. We investigated possible correlations between $\mathrm{EC}_{50}, K_{\mathrm{d}}$, and fold-induction using parametric and non-parametric regression tools in GraphPad Prism, v.3.

\section{RESULTS}

\section{EREc38 binding increases ER $\alpha$ susceptibility to trypsin digestion when occupied by $E_{2}$ or 4-OHT}

To examine the effect of ERE binding on the conformational state of baculovirus-expressed, $\operatorname{rhER} \alpha$ 

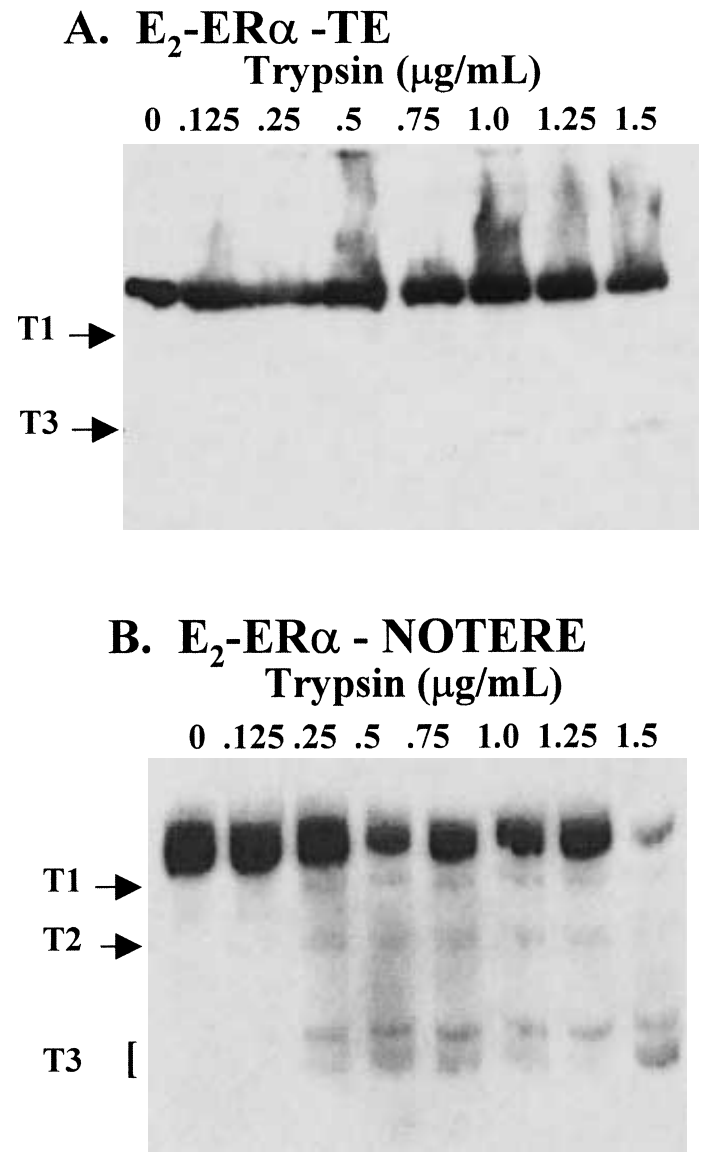

\section{C. $\quad E_{2}$-ER $\alpha-$ EREc38}

Trypsin $(\mu \mathrm{g} / \mathrm{mL})$

$\begin{array}{llllllll}0 & .125 & .25 & .5 & .75 & 1.0 & 1.25 & 1.5\end{array}$

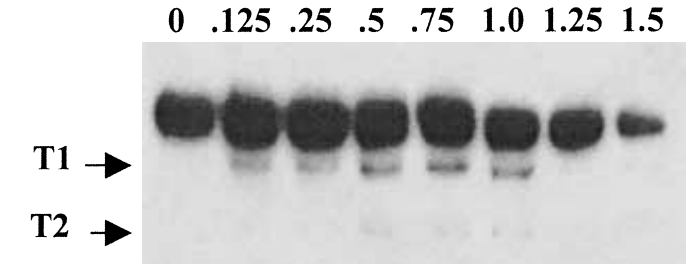

D. 4-OHT-ER $\alpha$ - NOTERE

Trypsin $(\mu \mathrm{g} / \mathrm{mL})$

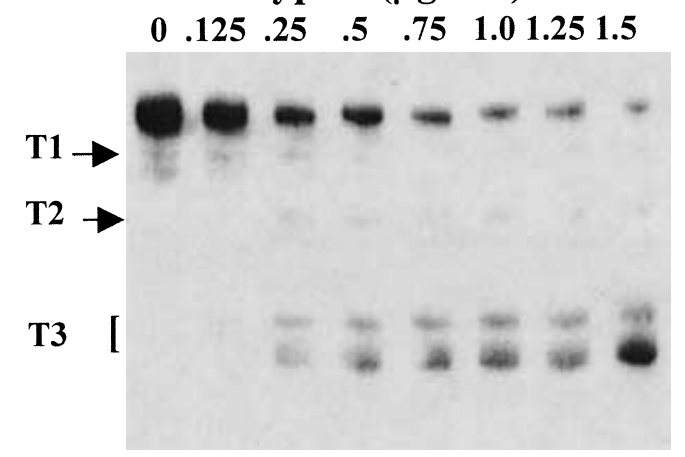

E. 4-OHT-ER $\alpha$ - EREc38

Trypsin $(\mu \mathrm{g} / \mathrm{mL})$

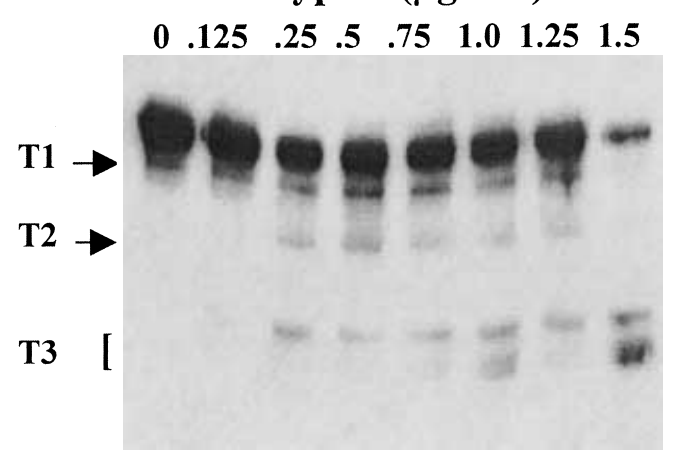

\section{T3}

FIGURE 1. ERE binding to ER $\alpha$ enhances trypsin proteolysis. Western blots of PVDF membranes probed with Ab-10 to ER $\alpha$. ER $\alpha\left(12 \cdot 5 \mathrm{nM}\right.$ final) was preincubated with $\mathrm{E}_{2}$ (A-C) or 4-OHT (D and E) followed by incubation with TE, NOTERE (B and D) and EREc38 (C and E) as detailed in Materials and Methods. The liganded $\mathrm{ER} \alpha$-DNA mix was then incubated with increasing concentrations of trypsin $(0-1 \cdot 5 \mu \mathrm{g} / \mathrm{ml}$, as indicated) for $10 \mathrm{~min}$ at RT. The reaction was terminated and the samples were applied to $10 \%$ polyacrylamide SDS-PAGE gels. Conditions for electrophoresis and Western blotting with ER $\alpha$ antibody Ab-10 are described in Materials and Methods. Sizes of protein markers are indicated in kDa. The sizes of the ER $\alpha$ bands are: $\mathrm{T} 1=57 \mathrm{kDa}, \mathrm{T} 2=45 \mathrm{kDa}, \mathrm{T} 3=36$ and $34 \mathrm{kDa}$ bands combined. 
TABLE 1. Summary of ER $\alpha$ interaction with select ERE sequences.

Comparison of the $\mathrm{EC}_{50}$ value for trypsin digestion of the intact $\mathrm{ER} \alpha$ band vs

$K_{\mathrm{d}}$ for $\mathrm{E}_{2}$-ER $\alpha$-ERE binding and fold-induction of luciferase activity in

CHO-K1 cells transiently transfected with $\mathrm{ER} \alpha$ and treated with $10 \mathrm{nM} \mathrm{E} \mathrm{E}_{2}$.

Details of the experiments from which these data are derived are described in

Materials and Methods. Values are means \pm s.E.M. for 3-11 experiments

\begin{tabular}{|c|c|c|c|c|}
\hline & $\begin{array}{l}\boldsymbol{K}_{\mathrm{d}} \text { for } \\
\mathbf{E}_{2} \text {-ER } \alpha-E R E \\
\text { binding }(n M)^{1}\end{array}$ & $\begin{array}{l}\text { Fold-induction } \\
\text { of luciferase } \\
\text { activity }\end{array}$ & $\begin{array}{l}\mathbf{E C}_{\mathbf{5 0}} \text { for } \\
\mathbf{E}_{\mathbf{2}} \mathbf{E R \boldsymbol { \alpha }} \\
(\operatorname{trypsin} \mu \mathrm{g} / \mathrm{ml})\end{array}$ & $\begin{array}{l}\mathbf{E C}_{50} \text { for } \\
\text { 4-OHT-ER } \boldsymbol{\alpha} \\
(\text { trypsin } \mu \mathrm{g} / \mathrm{ml})\end{array}$ \\
\hline \multicolumn{5}{|l|}{ DNA } \\
\hline NOTERE & $\mathrm{N} / \mathrm{A}^{2}$ & $\mathrm{~N} / \mathrm{A}^{2}$ & $1 \cdot 21$ & $1 \cdot 57$ \\
\hline $\mathrm{pS} 2$ & $1.069 \pm 0.03$ & $2 \cdot 41 \pm 0 \cdot 21$ & 0.89 & $0 \cdot 91$ \\
\hline $1 \mathrm{EREc} 38$ & $0 \cdot 089 \pm 0 \cdot 0088$ & $3 \cdot 71 \pm 0 \cdot 31$ & $0 \cdot 81$ & $0 \cdot 84$ \\
\hline 2 EREc 38 & $0 \cdot 038 \pm 0 \cdot 0086$ & $6 \cdot 34 \pm 0 \cdot 81$ & $0 \cdot 70$ & $0 \cdot 71$ \\
\hline $3 \mathrm{EREc} 38$ & $0 \cdot 0024 \pm 0 \cdot 0001$ & $24 \cdot 86 \pm 3 \cdot 93$ & $0 \cdot 61$ & $0 \cdot 51$ \\
\hline 4 EREc38 & $0 \cdot 018 \pm 0 \cdot 0016$ & $29 \cdot 96 \pm 5 \cdot 60$ & $0 \cdot 35$ & $0 \cdot 22$ \\
\hline
\end{tabular}

occupied by either $\mathrm{E}_{2}$ or 4-OHT, ER $\alpha$ was incubated with EREc38 and subjected to limited trypsin proteolysis in the presence of ERE-containing oligomers or a DNA sequence containing no EREs, called 'NOTERE' for simplicity. Figure 1 shows Western blots of five representative trypsin digestion experiments in which $\mathrm{ER} \alpha$, occupied by either $\mathrm{E}_{2}$ or 4-OHT, was incubated with TE (Fig. 1A), NOTERE (Fig. 1B and D) and EREc38 (Fig. 1C and E). Without trypsin treatment, Western blotting of $\mathrm{E}_{2}-\mathrm{ER} \alpha$ with a $\mathrm{C}$-terminal specific monoclonal antibody to $\mathrm{ER} \alpha, \mathrm{Ab}-10$, revealed the most prominent band to be $66 \mathrm{kDa}$ (Fig. 1A-E). This corresponds in size to intact ER $\alpha$. Thus, there was no degradation of ER $\alpha$ with incubation with TE buffer or with DNA oligomers at RT prior to trypsin digestion. Cleavage of $\mathrm{ER} \alpha$ by trypsin creates a concentration-dependent disappearance of the $66 \mathrm{kDa}$ intact band concurrent with the appearance of increasingly smaller digestion products, i.e. 60 , 55,45 and $36-34 \mathrm{kDa}$.

Incubation of $\mathrm{ER} \alpha$ with trypsin and either $\mathrm{E}_{2}$ or 4-OHT in the presence of a non-cognate DNA sequence (NOTERE) or TE buffer alone resulted in digestion patterns comparable to patterns observed without added DNA (Fig. 1A-C). These results agree with a recent report which detailed ER $\alpha$ conformational changes induced by ligand binding (Kraichely et al. 2000). When ER $\alpha$ was incubated with EREc38 instead of NOTERE, however, the results diverged from both our NOTERE results and other published findings (Kraichely et al. 2000) (Fig. 1C and E). ER $\alpha$ is more sensitive to trypsin digestion when bound to EREc38. This is readily seen in the densitometric quantitation of the ER $\alpha$

www.endocrinology.org band intensities for repeated trypsin digestion experiments of $\mathrm{E}_{2^{-}}$and 4-OHT-occupied ER $\alpha$ incubated with NOTERE or EREc38 shown in Fig. 2. The $\mathrm{EC}_{50}$ value for disappearance of the intact ER $\alpha$ band decreased from 1.2 and $1.5 \mu \mathrm{g} / \mathrm{ml}$ trypsin for $\mathrm{E}_{2}$ - and 4-OHT-occupied $\mathrm{ER} \alpha$ receptor respectively, in the presence of NOTERE, to $0 \cdot 81$ and $0.84 \mu \mathrm{g} / \mathrm{ml}$ trypsin with the addition of EREc38 (Fig. 2, Table 1). This increased sensitivity of ER $\alpha$ to trypsin digestion in the presence of EREc38 suggests that conformational changes in addition to those induced by ligand binding occur upon interaction with EREc38, reflecting the allosteric effect of DNA on ER $\alpha$ conformation (Lefstin \& Yamamoto 1998).

\section{Comparison of ERa digestion when incubated with EREc38 vs pS2}

We reported a correlation between the apparent binding affinity $\left(K_{\mathrm{d}}\right)$ of $\mathrm{ER} \alpha$ binding to specific ERE sequences, as determined by EMSA, and $\mathrm{E}_{2}$-induced transactivation potential in transient transfection experiments (Klinge et al. 1992b, $1996 a$, 2001, Tyulmenkov et al. 2000). As anticipated, a trypsin concentration-dependent loss of intact $\mathrm{ER} \alpha$ was detected for both $\mathrm{E}_{2^{-}}$and 4-OHT-occupied ER $\alpha$ bound to pS2 (Fig. 3A and B). Densitometric quantitation of the ER $\alpha$ band intensities for repeated trypsin digestions of $\mathrm{ER} \alpha$ incubated with pS2 gave an identical $\mathrm{EC}_{50}$ value of $0.89 \mu \mathrm{g} / \mathrm{ml}$ for $\mathrm{E}_{2}-$ and $4-\mathrm{OHT}-\mathrm{ER} \alpha$ respectively (Fig. 3C and D). There is no statistical difference between the $\mathrm{EC}_{50}$ values for trypsin digestion of $\mathrm{ER} \alpha$ bound to $\mathrm{pS} 2$ vs EREc38. 


\section{A. Trypsin digestion of $\mathrm{E}_{\mathbf{2}}$-ER $\alpha$-NOTERE}

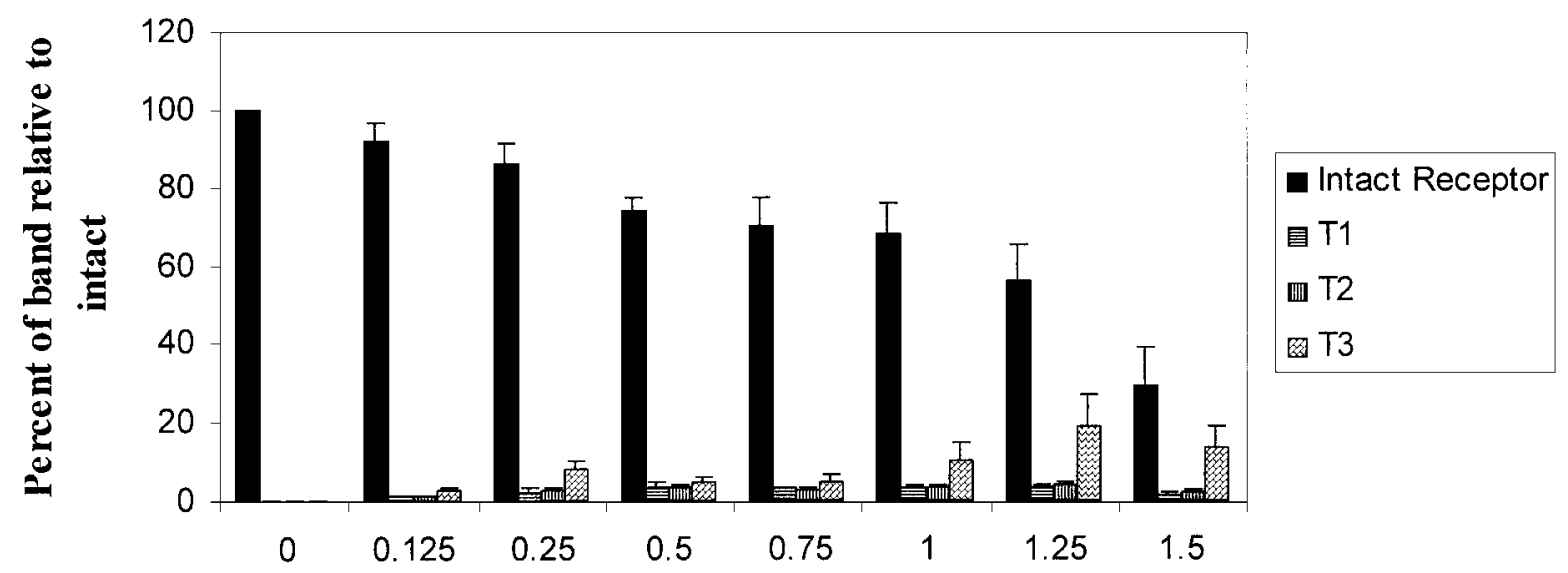

Trypsin concentration in $\mu \mathrm{g} / \mathrm{ml}$

\section{B. Trypsin digestion of 4-OHT-ER $\alpha$-NOTERE}

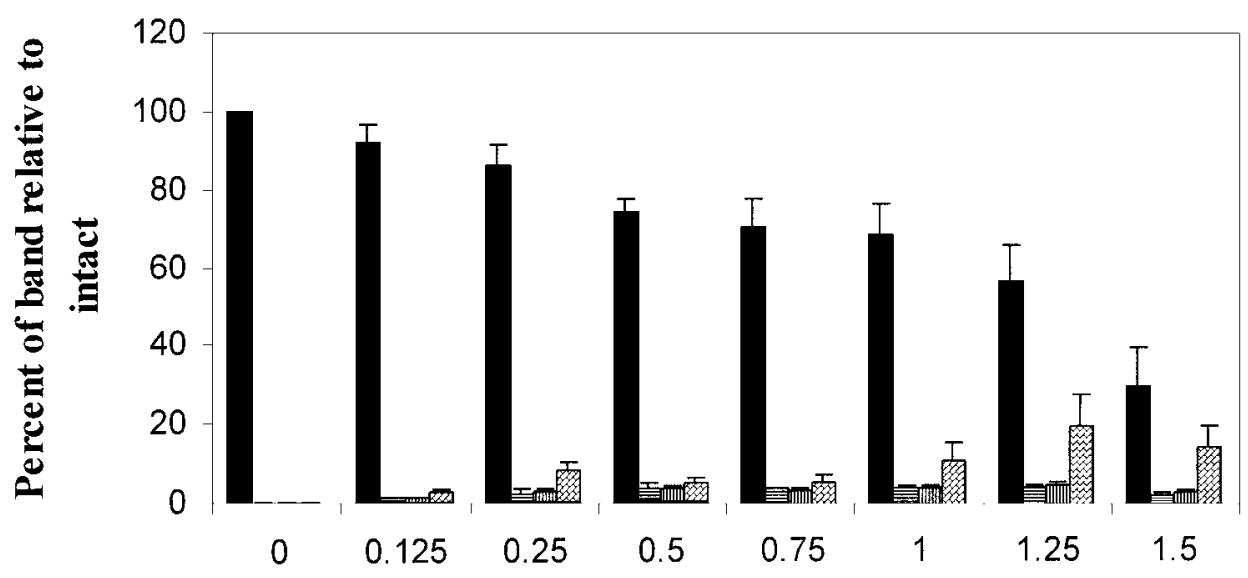

Trypsin concentration in $\mu \mathrm{g} / \mathrm{ml}$

FIGURE 2. (A and B, legend opposite).

Effect of multiple tandem copies of EREc38 on sensitivity of ER $\alpha$ to trypsin digestion

Multiple copies of EREc38 cloned head-to-tail as a tandem array demonstrated cooperative $\mathrm{E}_{2}$-ER $\alpha$ binding and synergistic transactivation potential (Tyulmenkov et al. 2000). This result, combined with the data showing that binding to 1 EREc38 enhanced trypsin digestion of ER $\alpha$ (Fig. $1 \mathrm{D}$ and $\mathrm{E}$ and Fig. $2 \mathrm{C}$ and $\mathrm{D}$ ), indicates that further ERa conformation changes may occur upon ER $\alpha$ binding to multiple tandem copies of EREc38. To test this hypothesis, we examined the effect of ER $\alpha$ binding to 2,3 and 4 tandem copies of EREc38 on ER $\alpha$ trypsin sensitivity. These experiments utilized the same ER $\alpha$ proteolysis assay described in Fig. 1 and Materials and Methods. As expected from the $K_{\mathrm{d}}$ and fold-induction values for these constructs ('Tyulmenkov et al. 2000), ER $\alpha$ incubated with 2, 3 or 4 EREc38 displayed increasing susceptibility to proteolysis by trypsin. Binding of $\mathrm{ER} \alpha$ to 2 EREc38 resulted in an $\mathrm{EC}_{50}$ of 0.70 and $0.71 \mu \mathrm{g} / \mathrm{ml}$ trypsin for $\mathrm{E}_{2}$ - and 4-OHT-ER $\alpha$ respectively (Fig. 4A and $\mathrm{B}$ and Fig. 5A and $\mathrm{B}$ ), whereas ER $\alpha$ 


\section{Trypsin digestion of $E_{2}-E R \alpha-E R E c 38$}

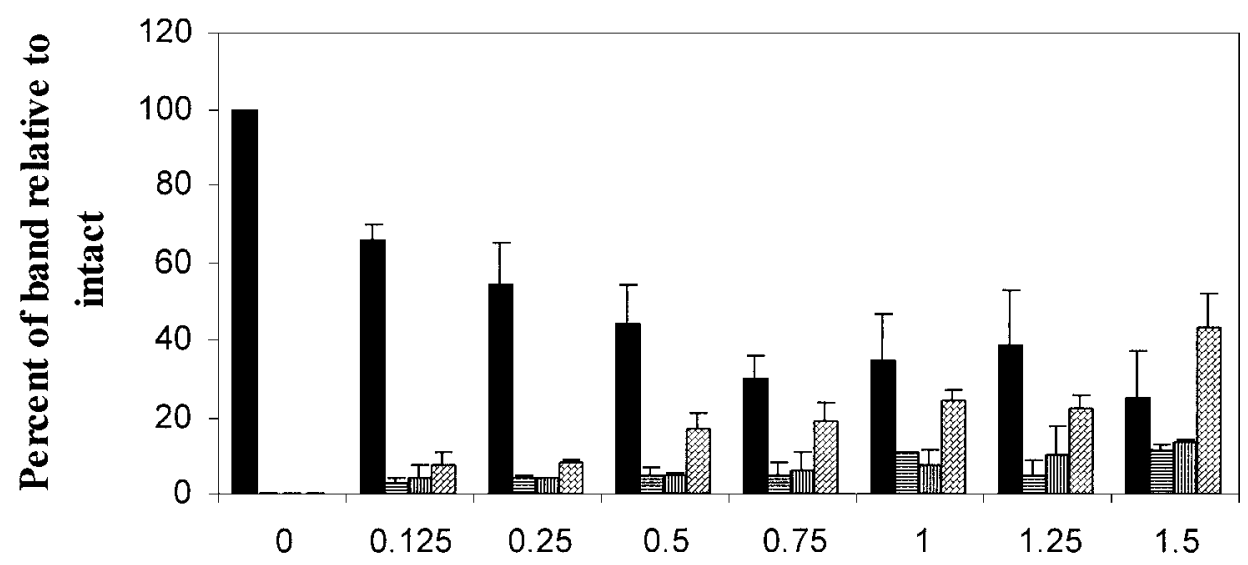

Tryps in concentration in $\mu \mathrm{g} / \mathrm{ml}$

\section{Trypsin digestion of 4-OHT-ER $\alpha$-EREc38}

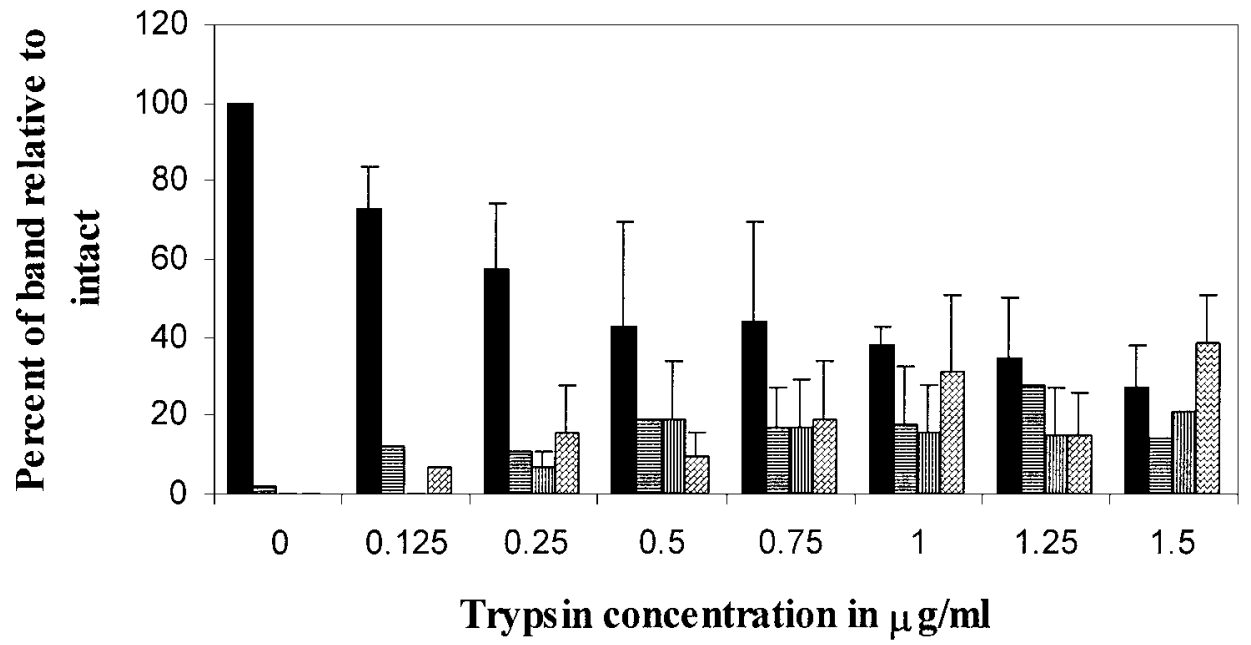

FIGURE 2. (C and D).

FIGURE 2 (opposite and above). Plot of densitometric scans of NOTERE- and EREc38bound ER digested by trypsin. The relative level of ER $\alpha$ in all bands was determined by densitometric scans of Western blots. The resulting numerical values for image intensity correlate to the amount of ER $\alpha$ protein recognized by Ab-10. The relative ER $\alpha$ amounts in the trypsin digestion bands are expressed relative to the intact, non-trypsinized ER $\alpha$ $66 \mathrm{kDa}$ band that was assigned a value of $100 \%$. (A and $\mathrm{B}$ ) Data from $\mathrm{E}_{2}$ - and 4-OHToccupied ER $\alpha$ incubated with the NOTERE DNA sequence respectively. (C and D) The same analysis applied to $\mathrm{E}_{2}$ - and 4-OHT-occupied ER $\alpha$ bound to EREc38 respectively. Data are means \pm S.E.M. of $n=3-5$ experiments. The sizes of the ER $\alpha$ bands are: $\mathrm{T} 1=57 \mathrm{kDa}, \mathrm{T} 2=45 \mathrm{kDa}, \mathrm{T} 3=36$ and $34 \mathrm{kDa}$ bands combined.

binding to 3 EREc38 showed 0.61 and $0.51 \mu \mathrm{g} / \mathrm{ml}$ trypsin for $\mathrm{E}_{2}$ - and 4-OHT-ER $\alpha$ respectively (Fig. $4 \mathrm{C}$ and $\mathrm{D}$ and Fig. 5C and D). Finally, ER $\alpha$ binding to 4 EREc38 yielded $\mathrm{EC}_{50}$ values of 0.35 and $0.22 \mu \mathrm{g} / \mathrm{ml}$ for $\mathrm{E}_{2-}$ and 4-OHT-occupied ER $\alpha$ respectively (Fig. 4E and $\mathrm{F}$ and Fig. $5 \mathrm{E}$ and $\mathrm{F}$ ). 
A. $\quad \mathbf{E}_{2}-\mathbf{E R} \alpha-\mathrm{pS} 2$

Trypsin $(\mu \mathrm{g} / \mathrm{mL})$

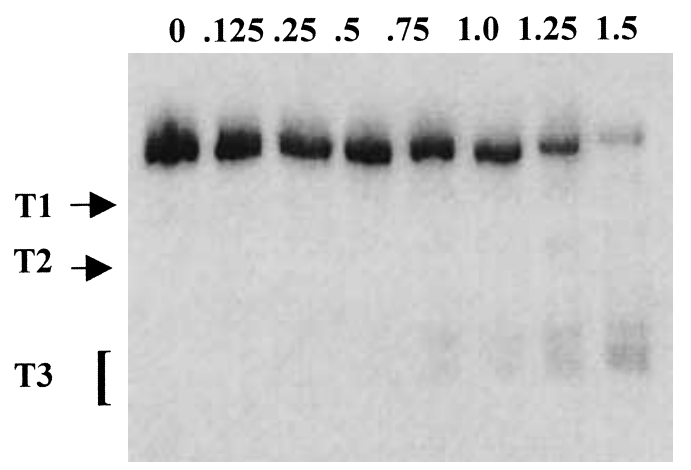

B. 4-OHT-ER $\alpha-\mathrm{pS2}$ Trypsin $(\mu \mathrm{g} / \mathrm{mL})$ $\begin{array}{llllllll}0 & .125 & .25 & .5 & .75 & 1.0 & 1.25 & 1.5\end{array}$

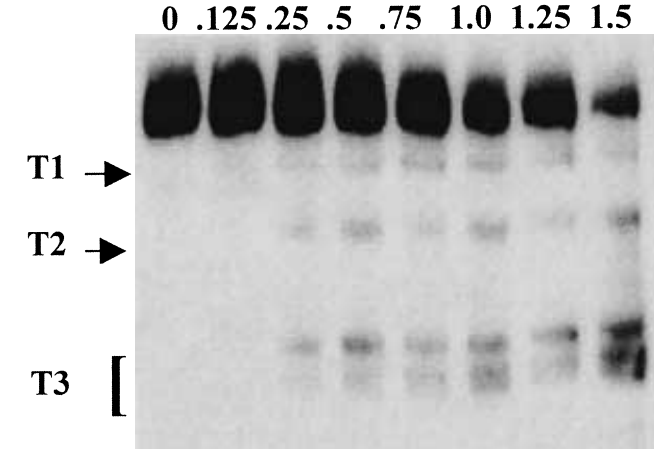

\section{Trypsin digestion of $\mathrm{E}_{2}-\mathrm{ER} \alpha-\mathrm{pS} 2$}

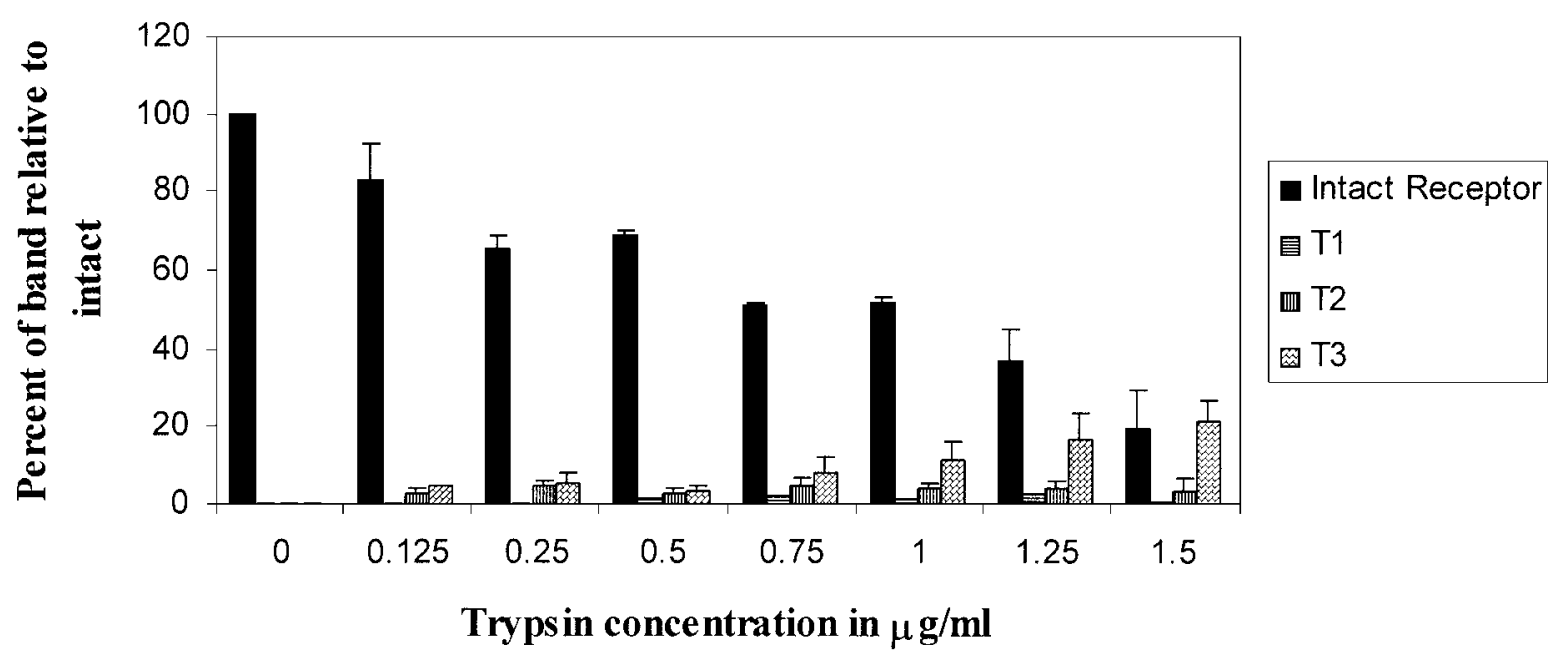

FIGURE 3. (A-C, legend opposite).

Incubation of $\mathrm{ER} \alpha$ with 2-4 tandem copies of EREc38 also generated stabilized $\mathrm{ER} \alpha$ tryptic digestion bands characteristic of each ligand, i.e. $28 \mathrm{kDa}$ for $\mathrm{E}_{2}$ and $25 \mathrm{kDa}$ for 4-OHT (Kraichely et al. 2000). Comparison of the $\mathrm{T} 4$ bands of $\mathrm{E}_{2 \text { - }}$ and 4-OHT-liganded 4 EREc38 in Fig. 6 clearly demonstrates this difference in the lowest visible MM band. These bands did not appear, at least at the trypsin concentrations used in this study, when $\mathrm{ER} \alpha$ was incubated without DNA, with NOTERE, with pS2, or with 1 copy of EREc38 (Figs 1 and 3). Therefore, the appearance of the smallest $\mathrm{ER} \alpha$ fragments, at the trypsin concentrations used here, is dependent upon $\mathrm{ER} \alpha$ interaction with multiple tandem copies of EREc38. Also, Fig. 6 highlights differences in sensitivity of $\mathrm{ER} \alpha$ bound with $\mathrm{E}_{2}$ vs 4-OHT. Importantly, increased numbers of tandem copies of EREc38 increased the sensitivity of ER $\alpha$ to trypsin digestion, resulting in the appearance of the low MM stabilized LBD fragments at lower trypsin concentration than those in the presence of non-cognate DNA, the $\mathrm{pS} 2$ natural, NOTERE, or 1 EREc38 (Figs 1 and 3). For example, this can be seen by comparing lane 6 in Fig. $1 \mathrm{C}$ $\left(\mathrm{E}_{2}-\mathrm{ER} \alpha-1 \mathrm{EREc} 38\right)$ with lane 6 in Fig. 4A, C and $\mathrm{E}\left(\mathrm{E}_{2}-\mathrm{ER} \alpha-2-4\right.$ EREc38). Furthermore, the 


\section{Trypsin digestion of 4-OHT-ER $\alpha-p S 2$}

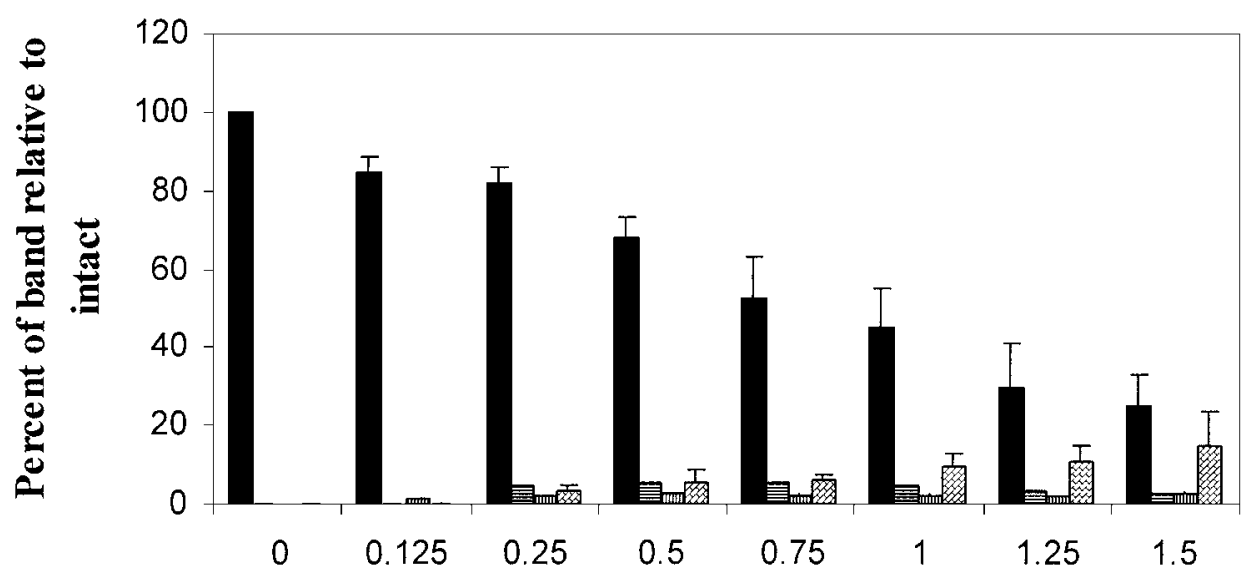

Trypsin concentration in $\mu \mathrm{g} / \mathrm{ml}$

FIGURE 3. (D).

FIGURE 3 (opposite and above). ER $\alpha$ binding to the pS2 ERE induces increased sensitivity to trypsin digestion. Shown are Western blots of PVDF membranes probed with $\mathrm{Ab}-10$ to $\mathrm{ER} \alpha$. ER $\alpha\left(12 \cdot 5 \mathrm{nM}\right.$ final), liganded by $\mathrm{E}_{2}$ (A) or 4-OHT (B), was incubated with pS2, following partial digestion with trypsin at the indicated concentrations. Conditions for electrophoresis and Western blotting are described in Materials and Methods and Fig. 1. The sizes of the ER $\alpha$ bands are: $\mathrm{T} 1=57 \mathrm{kDa}$ band, $\mathrm{T} 2=45 \mathrm{kDa}, \mathrm{T} 3=36$ and $34 \mathrm{kDa}$ bands combined. (C and D) Quantitation of the relative amounts of $\mathrm{ER} \alpha$ in all bands resulting from trypsin digestion of $\mathrm{E}_{2}-\mathrm{ER} \alpha(\mathrm{C})$ or 4-OHT-ER $\alpha$ (D) bound to $\mathrm{pS} 2$ ( $n=3$ experiments each). Quantitation was performed as described in Materials and Methods and Fig. 2. Values are means \pm s.E.M of three experiments.

ER $\alpha$-trypsin digestion patterns generated by the multiple EREc38 repeats resemble those produced at significantly higher trypsin concentrations and in the absence of ERE binding as reported recently (Kraichely et al. 2000). These results indicate that $\mathrm{ER} \alpha$ interaction with multiple tandem copies of EREc38 alters ER $\alpha$ conformation in a way that increases $\mathrm{ER} \alpha$ sensitivity to trypsin digestion.

\section{Correlation of $\mathrm{EC}_{50}$ of trypsin digestion of intact ER $\alpha, K_{d}$ of ER $\alpha$ for ERE sequences, and fold-induction of ERE-driven luciferase reporters in response to $\mathrm{E}_{2}$}

We investigated whether there was a correlation between the $\mathrm{EC}_{50}$ values for trypsin digestion determined here with the values for ER $\alpha$-EREc38 binding affinity $\left(K_{\mathrm{d}}\right)$ and fold-induction of reporter gene activity of the same ER $\alpha$-EREc38 combinations, determined previously (Tyulmenkov et al. 2000). The $r^{2}$-value for the correlation between $\mathrm{EC}_{50}$ trypsin concentration and $K_{\mathrm{d}}$ for $\mathrm{E}_{2}-\mathrm{ER} \alpha$

www.endocrinology.org interaction with $1,2,3$ and 4 EREc38 is $0 \cdot 5$ (Fig. 7A). For the $\mathrm{EC}_{50}-\mathrm{E}_{2}$-induced reporter gene expression correlation, the $r^{2}$-value is 0.82 (Fig. 7B). Therefore, there appears to be a stronger correlation between sensitivity to trypsin digestion and foldinduction of reporter gene expression for $E_{2}-E R \alpha$ interaction with $1,2,3$ and 4 EREc38 than with $K_{\mathrm{d}}$ values.

The $\mathrm{EC}_{50}$ value for 4-OHT-liganded ER $\alpha$ incubated with NOTERE indicates reduced susceptibility to trypsin digestion as compared to $\mathrm{E}_{2}-\mathrm{ER} \alpha$ incubated with NOTERE. The $\mathrm{EC}_{50}$ values for trypsin digestion for 4-OHT-ER $\alpha$ incubated with 1 , 2, 3 and 4 EREc38, however, were unexpectedly similar to those of $\mathrm{E}_{2}-\mathrm{ER} \alpha$ bound to the same EREs. As the number of tandem repeats of EREc38 increased, the $\mathrm{EC}_{50}$ value decreased (Fig. 7C). This result was not expected given the lack of cooperativity of binding of 4-OHT-ER $\alpha$ to three or more tandem repeats of EREc38 (Klinge et al. $1992 b, 1997 b)$ and with 4-OHT's antagonist activity with ER $\alpha$ in MCF-7 and CHO-K1 cells (Klinge 
A. $E_{2}-E R \alpha-2 E R E c 38$

Trypsin

$(\mu \mathrm{g} / \mathrm{mL})$

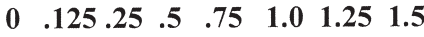

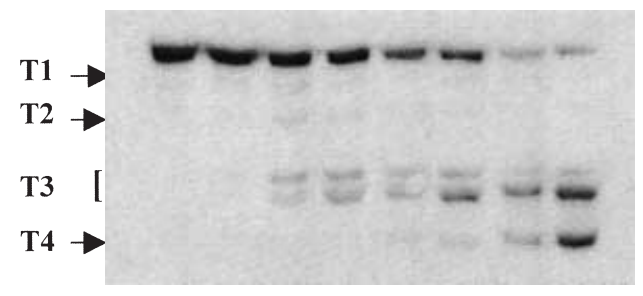

C. $E_{2}-E R \alpha-3 E R E c 38$

Trypsin

$(\mu \mathrm{g} / \mathrm{mL})$

$\begin{array}{llllllll}0 & .125 & .25 & .5 & .75 & 1.0 & 1.25 & 1.5\end{array}$

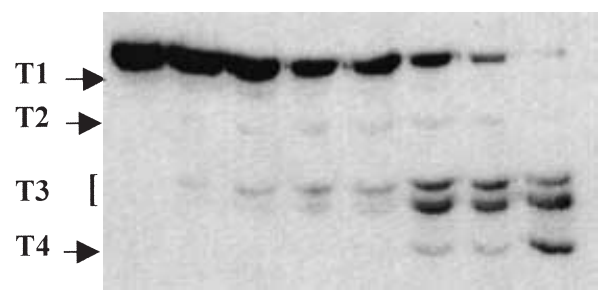

E. $E_{2}-E R \alpha-4 E R E c 38$

Trypsin

$(\mu \mathrm{g} / \mathrm{mL})$

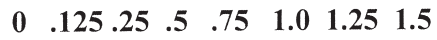

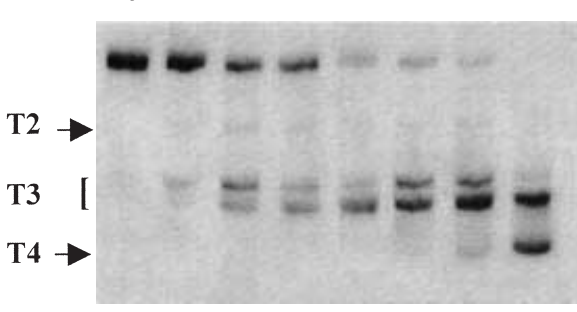

B. 4-OHT-ER $\alpha$ - 2EREc38

Trypsin

$(\mu \mathrm{g} / \mathrm{mL})$

$\begin{array}{lllllll}0 & .125 .25 & .5 & .75 & 1.0 & 1.25 & 1.5\end{array}$

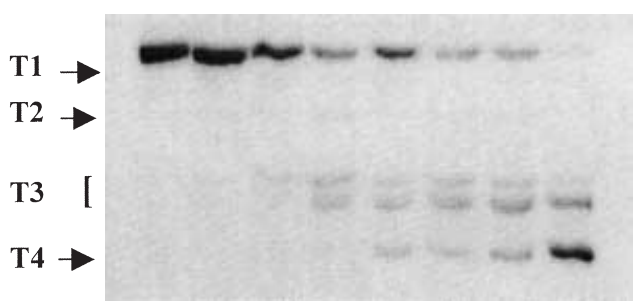

D. 4-OHT-ER $\alpha$ - 3EREc38

Trypsin

$(\mu \mathrm{g} / \mathrm{mL})$

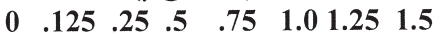

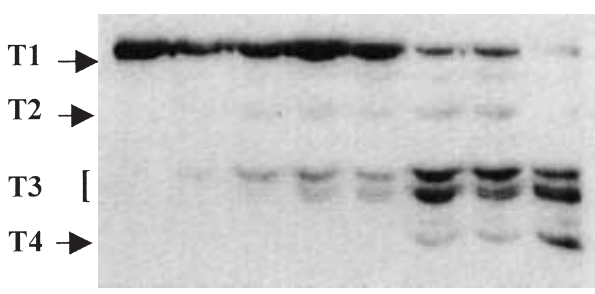

F. 4-OHT-ER $\alpha$ - 4EREc38

Trypsin

$(\mu \mathrm{g} / \mathrm{mL})$

$\begin{array}{llllllll}0 & .125 & .25 & .5 & .75 & 1.0 & 1.25 & 1.5\end{array}$

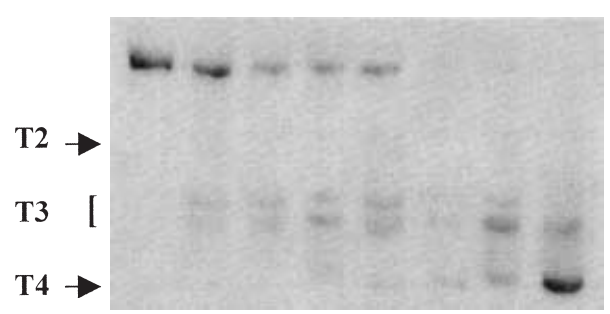

FIGURE 4. ER $\alpha$ binding to multiple tandem copies of EREc38 further enhances trypsin proteolysis. Shown are Western blots of PVDF membranes probed with Ab-10 to ER $\alpha$. ER $\alpha(12 \cdot 5 \mathrm{nM}$ final), liganded by $\mathrm{E}_{2}(\mathrm{~A}, \mathrm{C}$ and $\mathrm{E})$ or 4-OHT $(\mathrm{B}, \mathrm{D}$ and $\mathrm{F})$, and incubated with two $(\mathrm{A}$ and $\mathrm{B})$, three $(\mathrm{C}$ and $\mathrm{D}$ ) or four (E and F) head-to-tail, tandem copies of EREc38, followed by partial digestion with the indicated trypsin concentrations. Western blotting and electrophoresis were performed as detailed in Materials and Methods and Fig. 1. Sizes of protein markers are indicated in kDa. The sizes of the ER $\alpha$ bands are: $\mathrm{T} 1=57 \mathrm{kDa}, \mathrm{T} 2=45 \mathrm{kDa}, \mathrm{T} 3=36$ and $34 \mathrm{kDa}$ bands combined, and $\mathrm{T} 4=28 \mathrm{kDa}(\mathrm{A}, \mathrm{C}$ and $\mathrm{E})$ or $25 \mathrm{kDa}(\mathrm{B}, \mathrm{D}$ and $\mathrm{F})$.

et al. 1997b, 1999, 2000, Tyulmenkov et al. 2000). While 4-OHT-ER $\alpha$ obviously exists in a different conformational state compared to $\mathrm{E}_{2}-\mathrm{ER} \alpha$ (Brzozowski et al. 1997, Shiau et al. 1998) and when bound to different EREs, at present, the exact mechanism accounting for the similarity in trypsin digestion patterns is uncertain. We postulate that in vivo, or in transfected cells, ER $\alpha$ interaction with coactivators and other coregulatory proteins induces further alterations in $\mathrm{ER} \alpha$ conformation. 


\section{DISCUSSION}

Lefstin \& Yamamoto (1998) proposed that response elements recognized by nuclear transcription factors, including members of the steroid/nuclear receptor superfamily, contain information that is interpreted by bound regulator factors. Based on Lefstin and Yamamoto's model, we postulated that DNA acts as an allosteric ligand whose binding alters ER's affinity for other ligands (Klinge et al. 1992b, 1996a, 1998, 2001, Sathya et al. 1997, Tyulmenkov et al. 2000). Other investigators have also proposed that DNA is an allosteric modulator of ER $\alpha$ activity (Wood et al. 1998). The present study is the first to address the hypothesis that the synergism of transcriptional activation and the cooperativity of $\mathrm{ER} \alpha$ binding to multiple tandem EREs result, at least in part, from allosteric, ERE-mediated changes in ER $\alpha$ conformation. Previous studies with glucocorticoid receptor (GR) showed that transcriptional synergism requires an intact DBD and LBD (Ingiguez-Lluhi et al. 1999), and our results with $\mathrm{ER} \alpha$ showing that $\mathrm{E}_{2}$, but not 4-OHT, synergistically activates reporter gene expression also implicate the ER $\alpha$ LBD in transcriptional synergism (Tyulmenkov et al. 2000). Our data showing that $\mathrm{ER} \alpha$ binding cooperativity correlates with transcriptional synergism implicate the DBD in these events as well (Tyulmenkov et al. 2000).

Here we showed that ERE binding makes ER $\alpha$ more sensitive to trypsin digestion and that increasing the number of tandem copies of EREc38 resulted in decreased $\mathrm{EC}_{50}$ values for trypsin digestion, indicating that binding of $\mathrm{ER} \alpha$ to multiple, tandem copies of EREc38 increases access of trypsin to digestion sites within EREc38-bound $\mathrm{ER} \alpha$. We conclude that ERE-bound ER $\alpha$ is in a different conformation than $\mathrm{ER} \alpha$ in solution or when interacting with a non-ERE containing section of the genome with low affinity. Further, we demonstrated that there is a correlation between the sensitivity of $\mathrm{ER} \alpha$ to trypsin digestion and cooperativity of ER $\alpha$-EREc38 binding and transcriptional activation. These results also support our recent report on the increased sensitivity of ERE-bound $\mathrm{ER} \alpha$ to $\alpha$-chymotrypsin digestion. In that set of experiments, we found both $\mathrm{E}_{2}$ - and 4-OHT-specific and ERE sequence-specific differences in ER $\alpha$ sensitivity to chymotrypsin digestion in the presence of EREc38 and natural EREs from estrogen target genes: pS2, progesterone receptor, and c-fos (Klinge et al. 2001). The ERE-mediated increase in $\mathrm{ER} \alpha$ sensitivity to chymotrypsin digestion correlated with $\mathrm{E}_{2^{-}}$ stimulated transcriptional activity from the same
EREs in transiently transfected CHO-K1 cells (Klinge et al. 2001). Transcriptional activity also correlates with the affinity of ER $\alpha$-ERE binding in vitro (Klinge et al. 2001).

Trypsin cleaves peptides C-terminal to lysine and arginine residues (Voet \& Voet 1990). Computer analysis of the ER $\alpha$ sequence revealed 57 possible trypsin digestion sites (Fig. 8). Because the recognition region for $\mathrm{ER} \alpha$ monoclonal antibody is amino acids (aa) 302-553, we compared the size of possible tryptic ER $\alpha$ fragments containing the epitope for ER $\alpha$ antibody $\mathrm{Ab}-10$ to those obtained experimentally (Figs 1, 3 and 4). The band of $57 \mathrm{kDa}$ detected corresponds to $\mathrm{ER} \alpha$ aa $32-555$ $(\mathrm{MM}=57 \cdot 5 \mathrm{kDa})$; the band of $45 \mathrm{kDa}$ detected corresponds to ER $\alpha$ aa $142-555(\mathrm{MM}=45 \cdot 3 \mathrm{kDa})$; the band of $34-36 \mathrm{kDa}$ corresponds to $\mathrm{ER} \alpha$ aa 245-555 $(\mathrm{MM}=34 \cdot 1 \mathrm{kDa})$ and aa 231-555 $(\mathrm{MM}=35.6 \mathrm{kDa})$; the band of $28 \mathrm{kDa}$ detected corresponds to $\mathrm{ER} \alpha$ aa $303-555(\mathrm{MM}=27 \cdot 7 \mathrm{kDa})$; and the band of $25 \mathrm{kDa}$ detected corresponds to $\mathrm{ER} \alpha$ aa $303-531 \quad(\mathrm{MM}=25 \cdot 1 \mathrm{kDa})$. These data correlate with the stability of the LBD and the relative proteolytic sensitivity of the $\mathrm{N}$-terminus of ERa (Seielstad et al. 1995).

Although the domains of steroid and nuclear receptors function independently (Webster et al. 1988), there are few quantitative analyses describing how interactions between domains within an intact receptor modulate receptor activity, i.e. for ER (Fritsch et al. 1992b, Kraus et al. 1995); for androgen receptor (Zhou et al. 1995, Karvonen et al. 1997); for retinoid $\mathrm{X}$ receptor (RXR) (Kurokawa et al. 1994); for GR (Segard-Maurel et al. 1996). Such experiments are important to define the role of ligand when a nuclear receptor is bound to DNA in vivo.

Partially purified, yeast-expressed ER $\alpha$ showed differential recognition by select $\mathrm{ER} \alpha$ antibodies when bound to a perfect ERE from the Xenopus laevis vitellogenin A1 gene vs an imperfect ERE from the human $\mathrm{pS} 2$ gene, indicating that receptor epitopes were differentially exposed in response to these different ERE sequences (Wood et al. 1998). The authors interpreted these data to indicate that interaction of the $\mathrm{ER} \alpha \mathrm{DBD}$ with the vitellogenin $\mathrm{A} 2$ and pS2 EREs brings about global changes in $\mathrm{ER} \alpha$ conformation. Together, this work, reports on thyroid receptor (TR) (Olson et al. 1997, 1998), and our recent analysis of ER $\alpha$ interaction with single copies of natural and synthetic EREs (Klinge et al. 2001) indicate that DNA architecture is important in determining receptor binding and ligand-activated transcription.

The effect of DNA binding on the protease sensitivity of other members of the steroid/nuclear 


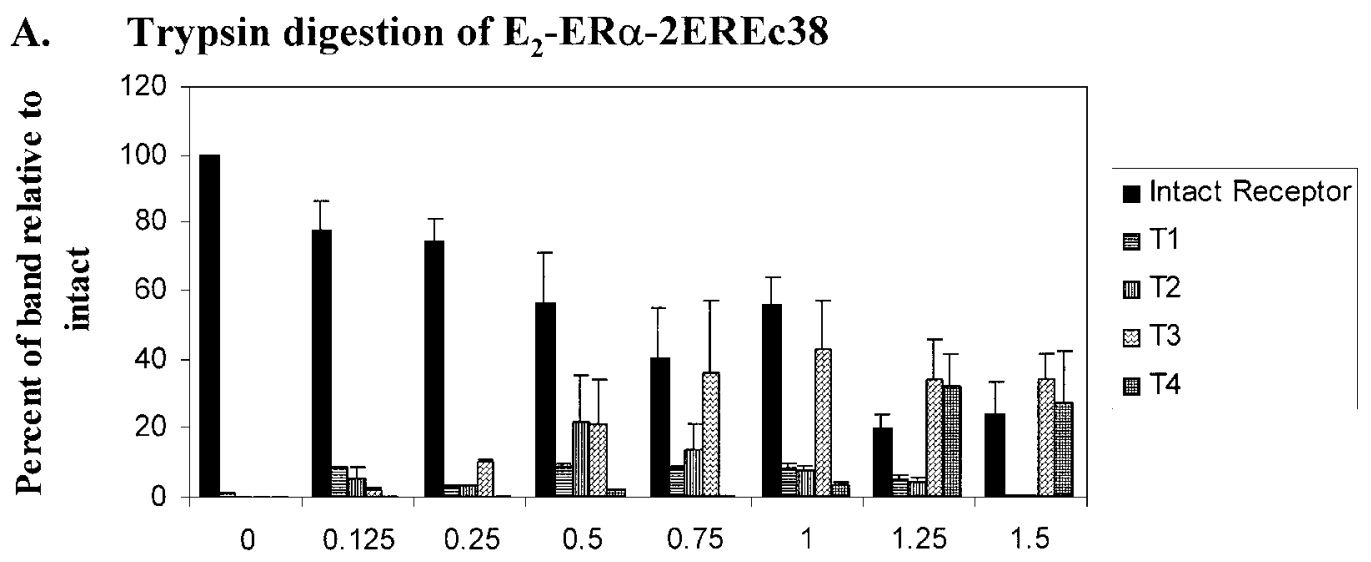

Tryps in concentration in $\mu \mathrm{g} / \mathrm{ml}$

B. Trypsin digestion of 4-OHT-ER $\alpha$-2EREc38

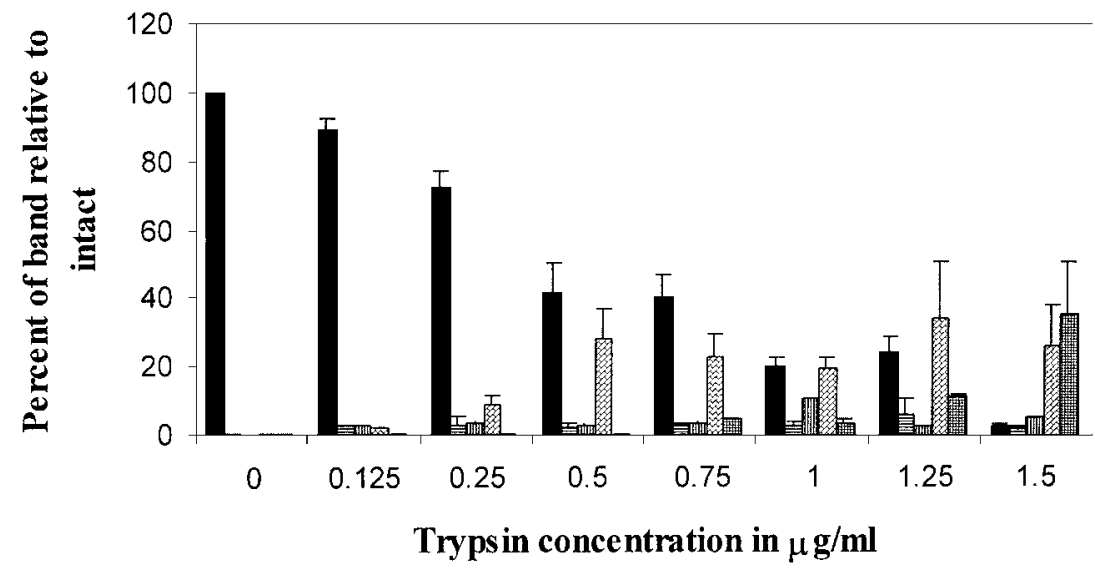

C. Trypsin digestion of $\mathbf{E}_{\mathbf{2}}$-ER $\alpha-3 E R E c 38$

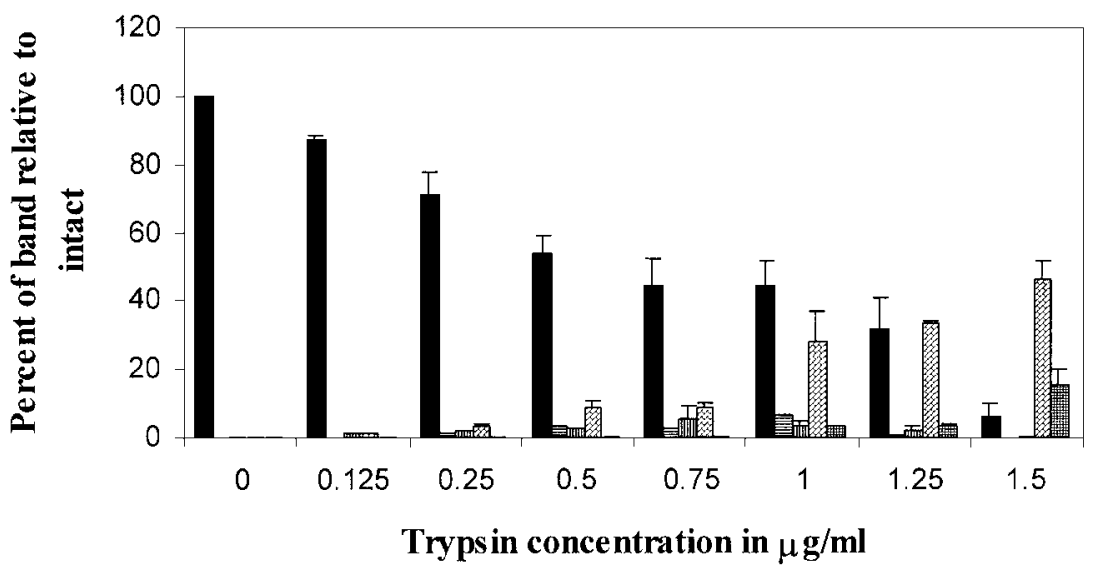

FIGURE 5. (A, B and C, legend opposite). 
D. Trypsin digestion of 4-OHT-ER $\alpha-3 E R E c 38$

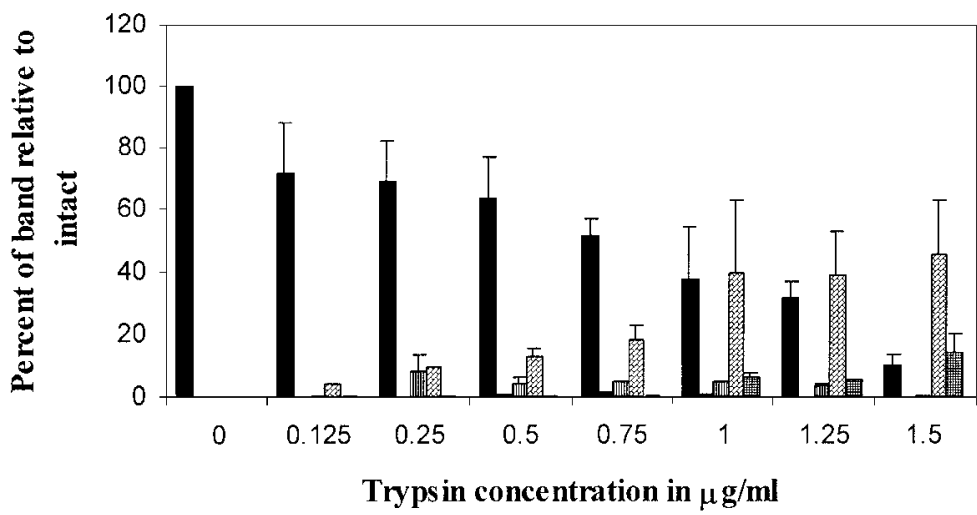

E. Trypsin digestion of $\mathbf{E}_{2}$-ER $\alpha-4 E R E c 38$

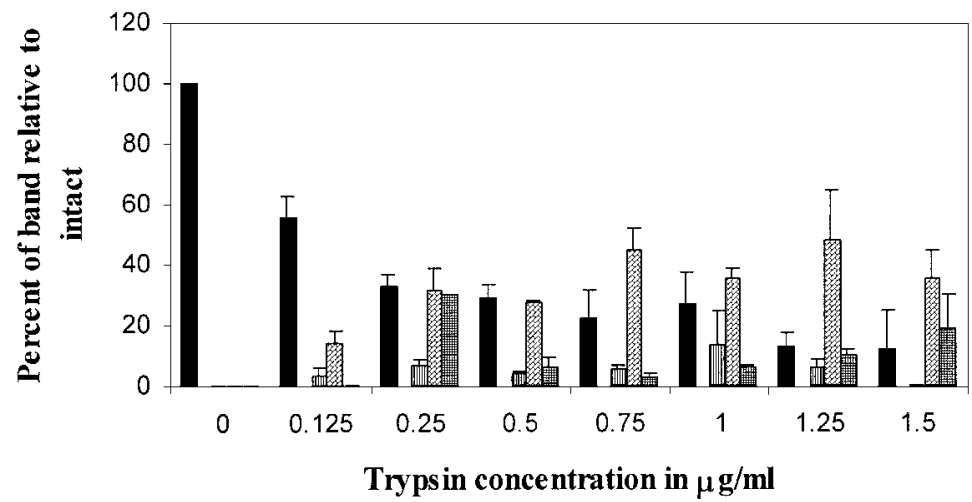

F. Trypsin digestion of 4-OHT-ER $\alpha$-4EREc38

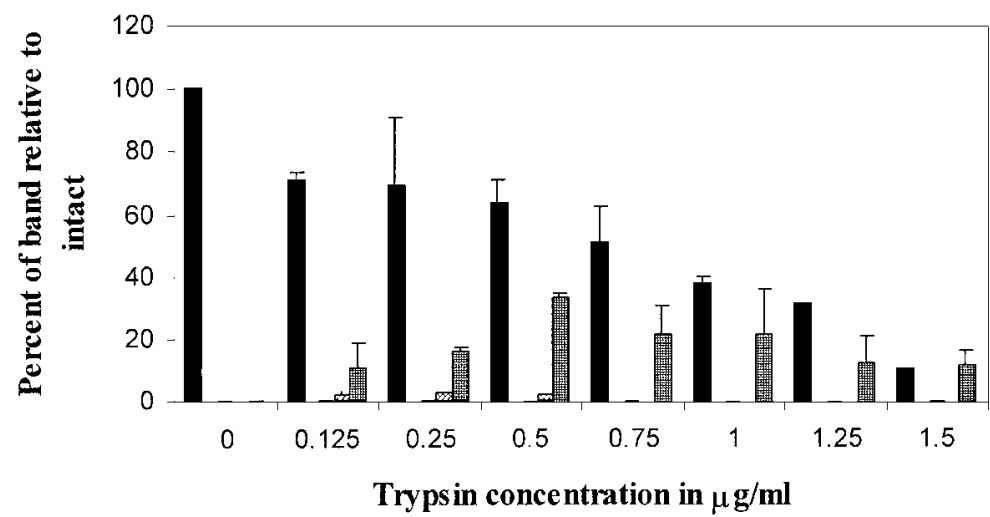

FIGURE 5. (D, E and F).

FIGURE 5 (opposite and above). Plot of densitometric scans of ER $\alpha$ bound to two to four tandem copies of EREc38 following trypsin digestion. (A-F) Quantitation of the data from the Western blots shown in panels A-F of Fig. 4. The relative amounts of ER $\alpha$ in all bands resulting from trypsin digestion of $\mathrm{E}_{2}$-ER $\alpha$ (A, C and E) or 4-OHT-ER $\alpha$ (B, D and F) were analyzed by densitometric scanning as described in Materials and Methods and Fig. 2. The bars display the means \pm s.E.M of several experiments $(n=3-5)$. T1 $=57 \mathrm{kDa}$ band, T2 $=45 \mathrm{kDa}$, T3 $=36$ and $34 \mathrm{kDa}$ bands combined, and $\mathrm{T} 4=28 \mathrm{kDa}(\mathrm{A}, \mathrm{C}$ and $\mathrm{E})$ or $25 \mathrm{kDa}(\mathrm{B}, \mathrm{D}$ and $\mathrm{F})$ bands. 


\section{4-EREc38 with $\mathrm{E}_{2}$ or 4-OHT}

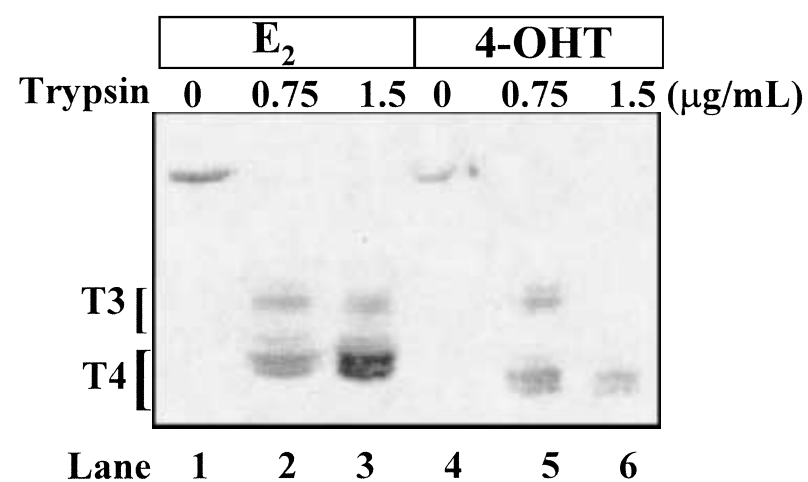

FIGURE 6. Comparison of the trypsin digestion products of $\mathrm{E}_{2}$ - vs 4-OHT-occupied $\mathrm{ER} \alpha$ incubated with 4 EREc38. Shown is a Western blot of a PVDF membrane probed with $\mathrm{Ab}-10$ to $\mathrm{ER} \alpha$. $\mathrm{ER} \alpha(12 \cdot 5 \mathrm{nM}$ final), liganded with $\mathrm{E}_{2}$ (lanes 1-3) or 4-OHT (lanes 4-6), and incubated with four head-to-tail, tandem copies of EREc38, followed by partial digestion with the indicated trypsin concentrations. Western blotting and electrophoresis were performed as detailed in Materials and Methods and Fig. 1. Sizes of protein markers are indicated in $\mathrm{kDa}$. The sizes of the $\mathrm{ER} \alpha$ bands are: $\mathrm{T} 3=36$ and $34 \mathrm{kDa}$ bands combined, and T4=28 kDa (lanes 2-3) or $25 \mathrm{kDa}$ (lanes 5-6). This experiment was repeated twice with similar results.

receptor superfamily has been reported. One study reported that binding of the triiodothyronine $\left(\mathrm{T}_{3}\right.$ )-activated TR/RXR heterodimer to transcriptionally active direct repeats of the ERE halfsite, i.e. 5'-AGGTCA-3' with four nucleotides separating the half-sites, i.e. DR4, induced protease-resistance of TR, but not RXR (Ikeda et al. 1996). This result corresponds with the observation that although the $\mathrm{T}_{3}$-TR/RXR heterodimer bound with similar affinity to a consensus or mutated DR4 oligomers in EMSA, transcription was not stimulated by $\mathrm{T}_{3}$ from mutant DR4s. In contrast, the vitamin $\mathrm{D}$ receptor was more sensitive to trypsin digestion when bound to a DR3 vs a non-consensus vitamin D response element (Towers \& Freedman 1998). We hypothesize that if these results are consistent for other members of the steroid/nuclear receptor superfamily, the specific nucleotide sequence of a receptor response element may modify ligand-induced transcription by altering receptor conformation.

Limited trypsin digestion of nuclei isolated from MCF-7 human breast cancer cells treated with $4-\mathrm{OHT}$ or $\mathrm{E}_{2}$ revealed $\left[{ }^{3} \mathrm{H}\right] 4-\mathrm{OHT}-\mathrm{ER} \alpha$ as a $67 \mathrm{kDa}$ and $\left[{ }^{3} \mathrm{H}\right] \mathrm{E}_{2}-\mathrm{ER} \alpha$ as a $60 \mathrm{kDa}$ protein respectively (Hutchens et al. 1987). This report indicated that 4-OHT better protected $\mathrm{ER} \alpha$ from
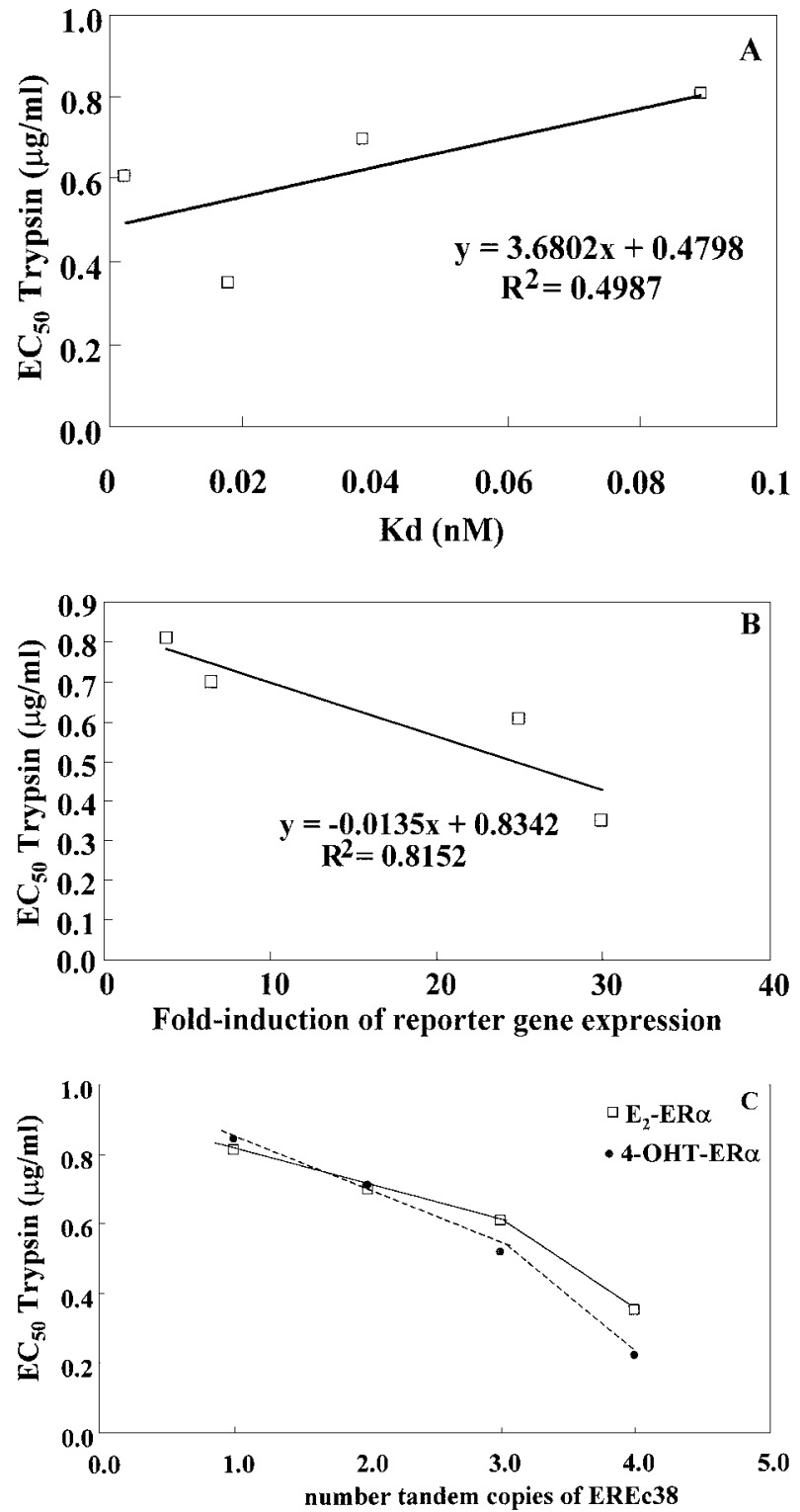

FIGURE 7. Relationship of $\mathrm{EC}_{50}$ for trypsin digestion with the affinity of ER-ERE interaction, $E_{2}$-induced transcription and number of tandem EREs.

(A) Correlation between $K_{\mathrm{d}}$ for $\mathrm{E}_{2}-\mathrm{ER} \alpha$ binding to one to four tandem copies of EREc38 and the $\mathrm{EC}_{50}$ for trypsin digestion of intact $\mathrm{E}_{2}-\mathrm{ER} \alpha$ bound to the same EREs. (B) Correlation between the fold-induction of reporter gene expression from one to four tandem copies of EREc38 in transiently transfected CHO-K1 cells treated with $10 \mathrm{nM} \mathrm{E}_{2}$ and the $\mathrm{EC}_{50}$ for trypsin digestion of intact $\mathrm{E}_{2}-\mathrm{ER} \alpha$ bound to the same EREs. Linear regression equations are given within panels. (C) Relationship of $\mathrm{EC}_{50}$ for trypsin digestion of intact $\mathrm{E}_{2}-\mathrm{ER} \alpha$ or $4-\mathrm{OHT}-\mathrm{ER} \alpha(\square$, solid line and $\bullet$, dotted line respectively) bound to one to four tandem copies of EREc38 and the number of EREs. Lines were plotted in Microsoft Excel 97. 


\section{Trypsin Cleavage Sites for ER $\alpha$}
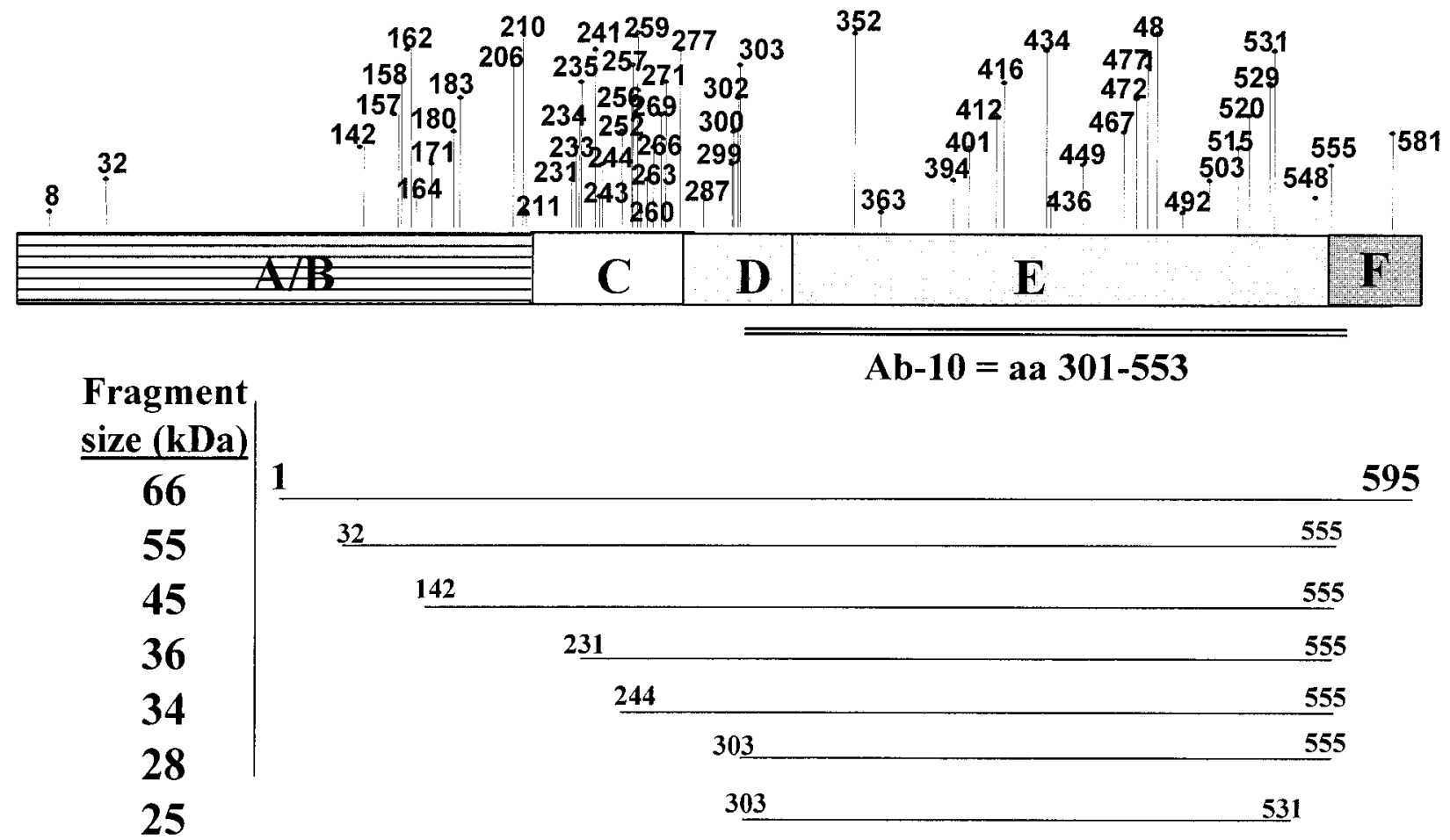

FIGURE 8. Potential trypsin cleavage sites of ER $\alpha$. Shown is the linear-domain structure of ER $\alpha$. The potential trypsin digestion sites, indicated by the lines and aa number at which digestion may occur, and the anticipated peptide mass of the fragments of the human ER $\alpha$ sequence recognized by Ab-10 (double line below the LBD) were analyzed using the ExPASy proteomics server as described in Materials and Methods. Anticipated trypsin digestion products recognized by $\mathrm{Ab}-10$ are indicated with the corresponding anticipated MM in $\mathrm{kDa}$. Where no definitive data exist regarding the exact cleavage sites utilized, the aa numbers represent estimated cleavage points based on size of digestion products.

trypsin digestion than $\mathrm{E}_{2} . \mathrm{E}_{2}$ vs antiestrogenspecific differences in the sizes of proteolytic fragments after chymotrypsin digestion of baculovirus-expressed $\operatorname{rhER} \alpha$ were also reported (Beekman et al. 1993). Here we report that when $\mathrm{ER} \alpha$ was bound to multiple tandem copies of EREc38, 4-OH'T increased the sensitivity of $\mathrm{ER} \alpha$ to trypsin. On the other hand, when $\mathrm{ER} \alpha$ was incubated with non-specific DNA, 4-OH'T displayed the 'classical' protective effect (Hutchens et al. 1987). Lastly, when $\mathrm{ER} \alpha$ was incubated with 1 EREc38 or pS2, 4-OHT effects were neutral relative to $\mathrm{E}_{2}$, providing further evidence of the allosteric effect DNA sequence on ER conformation. Other investigators (Brown \& Sharp 1990, Emmas et al. 1992, Anderson et al. 1998) and we have reported that $\mathrm{E}_{2}-\mathrm{ER} \alpha$ and antiestrogenliganded $\mathrm{ER} \alpha$ show different mobilities when bound to an ERE in EMSA (Klinge et al. 1996a), indicating ligand-specific differences in $\mathrm{ER} \alpha$ con- formation when bound to an ERE. However, not all studies detected conformational differences in $\mathrm{E}_{2}-\mathrm{ER} \alpha$ vs antiestrogen-liganded $\mathrm{ER} \alpha$. For example, both $\mathrm{E}_{2}$ and 4-OH'T induced similar decreases in surface hydrophobicity of $\operatorname{ER} \alpha$ as detected by PEG-palmitate affinity partitioning (Fritsch et al. 1992a).

The collected observations indicating ligandspecific changes in receptor conformation within the LBD are substantiated by the elucidation of the LBD crystal structure of $\mathrm{ER} \alpha$ (Brzozowski et al. 1997, Shiau et al. 1998, Pike et al. 1999). These studies indicate that, when liganded by $\mathrm{E}_{2}$, the LBD is folded into a compact structure in which the ligand is completely buried within a hydrophobic pocket. In contrast, when liganded by the antiestrogen RAL, the extended side chain of RAL protrudes from the pocket between helices 3 and 11, altering the conformation of the LBD (Brzozowski et al. 1997). It is generally agreed that the compact 
structure of ligand-bound LBD makes it more resistant to protease digestion. Ligand-specific conformational changes are thought to facilitate the dissociation of the protein components associated with non-activated ER, e.g. hsp90, hsp70, p56 and other proteins (Klinge et al. 1997a), and to unmask the DBD. Recent guanidine hydrochloride denaturation studies using ER $\alpha$ LBD show that the LBD undergoes a two-phase unfolding process and that occupation of the $\mathrm{ER} \alpha \mathrm{LBD}$ by $\mathrm{E}_{2}$ protects against denaturation (Gee et al. 2001). These data suggest a role for $\mathrm{E}_{2}$ in stabilizing the overall conformation of the ER $\alpha$ LBD (Gee et al. 2001). We suggest that, subsequent to ERE binding, further conformational changes critical for interaction with coactivators and with components of the transcriptional activation complex (Klinge 2000) occur within the ER $\alpha \mathrm{LBD}$ in a ligand-specific manner. Alterations in ER $\alpha$ conformation may also be propagated from the LBD to the ER $\alpha$ N-terminus (Kraus et al. 1995).

In summary, the observations reported here indicate that DNA allosterically modulates the conformation of the $\mathrm{LBD}$ of $\mathrm{ER} \alpha$, resulting in enhanced susceptibility to proteolysis by trypsin. Binding of ER $\alpha$ to the imperfect ERE palindrome from the pS2 gene or to one or more tandem copies of EREc38 altered ER $\alpha$ conformation as detected by a decrease in the $\mathrm{EC}_{50}$ for trypsin digestion. In contrast to our expectation that binding of $\mathrm{E}_{2}-\mathrm{ER} \alpha$ to three or four copies of EREc38 would result in a dramatic increase sensitivity to trypsin, a hypothesis based on our earlier observations of (i) cooperative $\mathrm{E}_{2}-\mathrm{ER} \alpha$ binding to three or four tandem copies of an ERE (Klinge et al. 1992, Tyulmenkov et al. 2000 ) and (ii) synergistic $\mathrm{E}_{2}$-dependent activation of reporter expression from three and four, but not one or two, tandem copies of EREc38, as evidenced by a decrease of $\mathrm{EC}_{50}$ (Sathya et al. 1997, Tyulmenkov et al. 2000), we detected a linear decrease in $\mathrm{EC}_{50}$ with one to three tandem copies of EREc38. Interestingly, the $\mathrm{EC}_{50}$ value for four tandem copies of EREc38 strayed from linearity (Fig. 6C). Thus, while the trypsin $\mathrm{EC}_{50}$ values did not demonstrate the sharp demarcation between two and three copies of EREc38 that the binding affinity and foldinduction of reporter activity in transient transfections did (Tyulmenkov et al. 2000), increasing copy number of EREc38 substantially increased susceptibility to trypsin digestion. Despite this lack of sharp change in $\mathrm{EC}_{50}$ between two and three tandem copies of EREc38, when we examined the fold-induction, $\mathrm{EC}_{50}$ and $K_{\mathrm{d}}$ values for each of the ERE-ER $\alpha$ pairs statistically, we detected a strong correlation between $\mathrm{EC}_{50}$ and fold-induction $(r=0.82, \quad P<0.05)$. Additionally, comparing the
$\mathrm{EC}_{50}$ values of $\mathrm{E}_{2}$-occupied $\mathrm{ER} \alpha$ for $1 \mathrm{EREc} 38$ or 4 EREc38 (0.81 vs 0.35$)$ establishes the presence of a conformational difference in the EREc38-bound $\mathrm{ER} \alpha$. Together these observations suggest that specific alterations in $\mathrm{ER} \alpha$ conformation result in cooperative binding of $\mathrm{E}_{2}-\mathrm{ER} \alpha$ to multiple EREs and transcriptional synergy. We also suggest that recruitment of coactivators also plays a role in transcriptional synergy. Our results support the hypothesis that the ERE sequence acts as an allosteric effector, altering ER conformation.

\section{ACKNOWLEDGEMENTS}

We thank Dr Valentyn V Tyulmenkov for his assistance with statistical evaluation of the data. This work was supported by NIH Grant R01 DK 53220 to C M K.

\section{REFERENCES}

Anderson I, Bartley CR, Lerch RA, Gray WG, Friesen PD \& Gorski J 1998 Estrogen receptor alpha requires no accessory factors for high-affinity binding to a consensus response element. Biochemistry 37 17287-17298.

Anolik JH, Klinge CM, Bambara RA \& Hilf R 1993 Differential impact of flanking sequences on estradiol- vs 4-hydroxytamoxifen-liganded estrogen receptor binding to estrogen responsive element DNA. Fournal of Steroid Biochemistry and Molecular Biology 46 713-730.

Anolik JH, Klinge CM, Hilf R \& Bambara RA 1995 Cooperative binding of estrogen receptor to DNA depends on spacing of binding sites, flanking sequence, and ligand. Biochemistry 34 2511-2520.

Anolik JH, Klinge CM, Brolly CL, Bambara RA \& Hilf R 1996 Stability of the ligand of estrogen response elementbound estrogen receptor depends on flanking sequences and cellular factors. Fournal of Steroid Biochemistry and Molecular Biology 59 413-429.

Beekman JM, Allan GF, Tsai SY, Tsai M-J \& O’Malley BW 1993 Transcriptional activation by the estrogen receptor requires a conformational change in the ligand binding domain. Molecular Endocrinology 7 1266-1274.

Brown M \& Sharp PA 1990 Human estrogen receptor forms multiple protein-DNA complexes. Fournal of Biological Chemistry $26511238-11243$.

Brzozowski AM, Pike AC, Dauter Z, Hubbard RE, Bonn T, Engstrom O, Ohma L, Greene GL, Gustafsson JA \& Carlquist M 1997 Molecular basis of agonism and antagonism in the oestrogen receptor. Nature 389 $753-758$.

Emmas CE, Fawell SE, Hoare SA Parker MG 1992 Effect of ligand binding and DNA binding on the structure of the mouse oestrogen receptor. Fournal of Steroid Biochemistry and Molecular Biology 41 291-299.

Fritsch M, Leary CM, Furlow JD, Ahrens H, Schuh TJ, Mueller GC \& Gorski J 1992a A ligand-induced conformational change in the estrogen receptor is localized in the steroid binding domain. Biochemistry 31 5303-5311. 
Fritsch M, Welch RD, Murdoch FE, Anderson I \& Gorski J $1992 b$ DNA allosterically modulates the steroid binding domain of the estrogen receptor. Fournal of Biological Chemistry 267 1823-1828.

Fritsch M, Anderson I \& Gorski J 1993 Structural characterization of the trypsinized estrogen receptor. Biochemistry 32 14000-14008.

Gee AC \& Katzenellenbogen JA 2001 Probing conformational changes in the estrogen receptor: evidence for a partially unfolded intermediate facilitating ligand binding and release. Molecular Endocrinology 15 421-428.

Hutchens TW, Li CM \& Besch PK 1987 Proteins associated with untransformed estrogen receptor in vitro. Biochemistry $265608-5616$.

Ikeda M, Wilcox EC \& Chin WW 1996 Different DNA elements can modulate the conformation of thyroid hormone receptor heterodimer and its transcriptional activity. Fournal of Biological Chemistry 271 23096-23104.

Ing NH, Beekman JM, Tsai SY, Tsai MJ \& O’Malley BW 1992 Members of the steroid hormone receptor superfamily interact with TFIIB (S300-II). Fournal of Biological Chemistry 267 17617-17623.

Ingiguez-Lluhi JA, Yamamoto KR \& Pearce D 1999 A short N-terminal motif defines a novel transcriptional synergy regulatory surface in steroid receptors. Proceedings of the Endocrine Society, 81st Annual Meeting, San Diego, California, June 12-15, 1999. Abstract OR47-4.

Karvonen U, Kallio PJ, Janne OA \& Palvimo JJ 1997 Interaction of androgen receptors with androgen response element in intact cells. Roles of amino- and carboxyl-terminal regions and the ligand. Fournal of Biological Chemistry 272 15973-15979.

Katzenellenbogen BS \& Korach KS 1997 Editorial: a new actor in the estrogen receptor drama-enter ER $\beta$. Endocrinology 138 861-862.

Klinge CM 1999 Role of estrogen receptor ligand and estrogen response element sequence on interaction with chicken ovalbumin upstream promoter transcription factor (COUP-TF). Fournal of Steroid Biochemistry and Molecular Biology 71 1-19.

Klinge CM 2000 Estrogen receptor interaction with coactivators and co-repressors. Steroids 65 227-251.

Klinge CM, Bambara RA \& Hilf R $1992 a$ Antiestrogenliganded estrogen receptor interaction with estrogen responsive element DNA in vitro. Fournal of Steroid Biochemistry and Molecular Biology 43 249-262.

Klinge CM, Peale Jr FV, Hilf R, Bambara RA \& Zain S $1992 b$ Cooperative estrogen receptor interaction with consensus or variant estrogen responsive elements in vitro. Cancer Research 52 1073-1081.

Klinge CM, Traish AM, Bambara RA \& Hilf R $1996 a$ Dissociation of 4-hydroxytamoxifen, but not estradiol or tamoxifen aziridine, from the estrogen receptor when the receptor binds estrogen response element DNA. Fournal of Steroid Biochemistry and Molecular Biology 57 51-66.

Klinge CM, Traish AM, Driscoll MD, Hilf R \& Bambara RA $1996 b$ Site-directed estrogen receptor antibodies stabilize 4-hydroxytamoxifen ligand, but not estradiol, and indicate ligand-specific differences in the recognition of estrogen response element DNA in vitro. Steroids 61 278-289.

Klinge CM, Brolly CL, Bambara RA \& Hilf R 1997a Hsp70 is not required for high affinity binding of purified calf uterine estrogen receptor to estrogen response element DNA in vitro. Fournal of Steroid Biochemistry and Molecular Biology $\mathbf{6 3}$ 283-301

Klinge CM, Silver BF, Driscoll MD, Sathya G, Bambara RA \& Hilf R $1997 b$ COUP-TF interacts with estrogen receptor, binds to estrogen response elements and half-sites, and modulates estrogen-induced gene expression. Fournal of Biological Chemistry 272 31465-31474.
Klinge CM, Studinski-Jones AL, Kulakosky PC, Bambara RA \& Hilf R 1998 Comparison of tamoxifen ligands on estrogen receptor interaction with estrogen response elements. Molecular and Cellular Endocrinology 143 79-90.

Klinge CM, Bowers JL, Kulakosky PC, Kamboj KK \& Swanson HI 1999 The aryl hydrocarbon receptor (AHR)/ AHR nuclear translocator (ARNT) heterodimer interacts with naturally occurring estrogen response elements. Molecular and Cellular Endocrinology 157 105-119.

Klinge CM, Kaur K \& Swanson HI 2000 The aryl hydrocarbon receptor interacts with estrogen receptor alpha and orphan receptors COUP-TFI and ERR 1 . Archives of Biochemistry and Biophysics 373 163-174.

Klinge CM, Jernigan SC, Smith SL, Tyulmenkov VV \& Kulakosky PC 2001 Estrogen response element sequence impacts the conformation and transcriptional activity of estrogen receptor $\alpha$. Molecular and Cellular Endocrinology 174 151-166.

Kraichely DM, Sun J, Katzenellenbogen JA \& Katzenellenbogen BS 2000 Conformational changes and coactivator recruitment by novel ligands for estrogen receptor-alpha and estrogen receptor-beta: correlations with biological character and distinct differences among SRC coactivator family members. Endocrinology 141 3534-3545.

Kraus WL, McInerney EM \& Katzenellenbogen BS 1995 Ligand-dependent, transcriptionally productive association of the amino- and carboxy-terminal regions of a steroid hormone nuclear receptor. PNAS 92 12314-12318.

Kurokawa R, DiRenzo J, Boehm M, Sugarman J, Gloss B, Rosenfeld MG, Heyman RA \& Glass CK 1994 Regulation of retinoid signaling receptor polarity and allosteric control of ligand binding. Nature 371 528-531.

Lazennec G, Ediger TR, Petz LN, Nardulli AM \& Katzenellenbogen BS 1997 Mechanistic aspects of estrogen receptor activation probed with constitutively active estrogen receptors: correlations with DNA and coregulator interactions and receptor conformational changes. Molecular Endocrinology 11 1375-1386.

Le Douarin B, Zechel C, Garnier J-M, Lutz Y, Tora L, Peirrat B, Heery D, Gronemeyer H, Chambon P \& Losson R 1995 The N-terminal part of TIF-1, a putative mediator of the ligand-dependent activation function $(\mathrm{AF}-2)$ of nuclear receptors, is fused to B-raf in the oncogenic protein T18. EMBO fournal 14 2020-2033.

Lefstin JA \& Yamamoto KR 1998 Allosteric effects of DNA on transcriptional regulators. Nature 392 885-888.

McKenna NJ, Lanz RB \& O’Malley BW 1999 Nuclear receptor coregulators: cellular and molecular biology. Endocrine Reviews 20 321-344.

Mangelsdorf DJ, Thummel C, Beato M, Herrlich P, Schutz G, Umesono K, Blumberg B, Kastner P, Mark M, Chambon P \& Evans RM 1995 The nuclear receptor superfamily: the second decade. Cell 83 835-839.

Olson DP \& Koenig RJ 1997 5-Flanking sequences in thyroid hormone response element half-sites determine the requirement of retinoid $\mathrm{X}$ receptor for receptor-mediated gene expression. Fournal of Biological Chemistry 272 9907-9914.

Olson DP, Sun B \& Koenig RJ 1998 Thyroid hormone response element architecture affects corepressor release from thyroid hormone receptor dimers. Fournal of Biological Chemistry 273 3375-3380.

Onate SA, Tsai SY, Tsai M-J \& O’Malley BW 1995 Sequence and characterization of a coactivator for the steroid hormone receptor superfamily. Science 270 1354-1357.

Pavlik EJ \& Coulson PB 1976 Hydroxylapatite 'batch' assay for estrogen receptor: increased sensitivity over present receptor assays. Fournal of Steroid Biochemistry 7 357-368. 
Peale FV, Ludwig LB, Zain S, Hilf R \& Bambara RA 1988 Properties of a high-affinity DNA binding site for estrogen receptor. PNAS 85 1038-1042.

Pike AC, Brzozowski AM, Hubbard RE, Bonn T, Thorsell AG, Engstrom O, Ljunggren J, Gustafsson JA \& Carlquist M 1999 Structure of the ligand-binding domain of oestrogen receptor beta in the presence of a partial agonist and a full antagonist. EMBO fournal 18 4608-4618.

Sadovsky Y, Webb P, Lopez G, Baxter JD, Fitzpatrick PM, Gizang-Ginsberg E, Cavailles V, Parker MG \& Kushner PJ 1995 Transcriptional activators differ in their responses to over-expression of TATA-box-binding protein. Molecular and Cellular Biology 15 1554-1563.

Sathya G, Wenzhou L, Klinge CM, Anolik JH, Hilf R \& Bambara RA 1997 Effects of multiple estrogen responsive elements, their spacing and location on estrogen response of reporter genes. Molecular Endocrinology 11 1994-2003.

Segard-Maurel I, Rajkowski K, Jibard N, Schwizer-Groyer G, Baulieu E-E \& Cadepond F 1996 Glucocorticoid steroid receptor dimerization investigated by analysis of receptor binding to glucocorticoid responsive elements using a monomer-dimer equilibrium mode. Biochemistry $\mathbf{3 5}$ 1634-1642.

Seielstad DA, Carlson KE, Kushner PJ, Greene GL \& Katzenellenbogen JA 1995 Analysis of the structural core of the human estrogen receptor ligand binding domain by selective proteolysis/mass spectrometric analysis. Biochemistry 34 12605-12615.

Shiau AK, Barstad D, Loria PM, Cheng L, Kushner PJ, Agard DA \& Greene GL 1998 The structural basis of estrogen receptor/coactivator recognition and the antagonism of this interaction by tamoxifen. Cell 95 927-937.

Towers TL \& Freedman LP 1998 Granulocyte-macrophage colony-stimulating factor gene transcription is directly repressed by the vitamin D3 receptor. Implications for allosteric influences on nuclear receptor structure and function by a DNA element. Fournal of Biological Chemistry 273 10338-10348.

Tyulmenkov VT \& Klinge CM 2001 A mathematical approach to predict the affinity of estrogen receptors $\alpha$ and $\beta$ binding to estrogen response elements, half-sites, and direct repeats. Molecular and Cellular Endocrinology 182 109-119.

Tyulmenkov VT, Jernigan SC \& Klinge CM 2000 Comparison of transcriptional synergy of estrogen receptors alpha and beta from multiple tandem estrogen response elements. Molecular and Cellular Endocrinology 165 151-161.

Voegel JJ, Meine MJS, Zechel C, Chambon P \& Gronemeyer H 1996 TIF2, a $160 \mathrm{kDa}$ transcriptional mediator for the ligand-dependent activation function AF-2 of nuclear receptors. EMBO Fournal 15 3667-3675.

Voet D \& Voet JG 1990 Biochemistry. New York: John Wiley and Sons.

Webster NJ, Green S, Jin JR \& Chambon P 1988 The hormonebinding domains of the estrogen and glucocorticoid receptors contain an inducible transcription activation function. Cell $\mathbf{5 4}$ 199-207.

Wood JR, Greene GL \& Nardulli AM 1998 Estrogen response elements function as allosteric modulators of estrogen receptor conformation. Molecular and Cellular Biology 18 1927-1934.

Zhou Z-X, Lane MV, Kemppainen JA, French FS \& Wilson EM 1995 Specificity of ligand-dependent androgen receptor stabilization: receptor domain interactions influence ligand dissociation and receptor stability. Molecular Endocrinology 9 208-218.

RECEIVED IN FINAL FORM 11 July 2001 ACCEPTED 20 July 2001 